\title{
Símbolos na arte rupestre sob o olhar da Arqueologia Cognitiva: considerações analíticas sobre o sítio Conjunto da Falha, Cidade de Pedra, Rondonópolis, Mato Grosso \\ Symbols in rock art through the eyes of Cognitive Archaeology: analytical considerations about the Conjunto da Falha site, Mato Grosso, Brazil
}

\author{
Carolina Guedes', Denis Vialou" \\ Museu de Arqueologia e Etnologia/USP. São Paulo, Brasil \\ "Museu Nacional de História Natural. Paris, França
}

\begin{abstract}
Resumo: O grande número de sítios existentes na região da Cidade de Pedra, localizada no município de Rondonópolis, Mato Grosso, aliado à variedade formal, temática e de técnicas aplicadas nas construções dos painéis rupestres, marcam fortemente a paisagem da região. Neste artigo, será analisado, mais detalhadamente, o sítio rupestre da Falha sob o viés da Arqueologia Cognitiva, reforçando a importância da relação estrutural entre suporte/registro gráfico na construção de uma linguagem simbólica. Unindo a materialidade do sítio da Falha com as propostas teóricas das ciências do conhecimento, será apresentada uma discussão sobre os registros rupestres socialmente organizados, que refletem as crenças e escolhas culturais do grupo pretérito responsável pela sua organização, em estreita relação com o suporte, como parte essencial da construção da mensagem, tornando-se uma categoria semântica em conjunto com os grafismos.
\end{abstract}

Palavras-chave: Arte rupestre. Cidade de Pedra. Simbolização. Estrutura.

\begin{abstract}
The large number of archaeological sites at Cidade de Pedra/Rondonópolis (MT) and the formal variety, themes and techniques that characterize its rock art strongly mark the landscape of the region. In this article,the Conjunto da Falha rock art site is analyzed in relative detail from the perspective of Cognitive Archaeology, reinforcing the importance of the structural relation between support/graphic records in the construction of a symbolic language. Putting together the materiality of the Conjunto da Falha rock art site with theoretical proposals from the cognitive sciences, a discussion of socially organized rock art records is presented here. Rock art reflects cultural beliefs and choices of past groups who were responsible for its organization. In close relationship with the material media, as essential part in the construction of the message, those beliefs and choices constitute a semantic category together with the painted units.
\end{abstract}

Keywords: Rock art. Cidade de Pedra. Symbolization. Structure.

GUEDES, Carolina; VIALOU, Denis. Símbolos na arte rupestre sob o olhar da Arqueologia Cognitiva: considerações analíticas sobre o sítio Conjunto da Falha, Cidade de Pedra, Rondonópolis, Mato Grosso. Boletim do Museu Paraense Emílio Goeldi. Ciências Humanas, v. 12, n. 1, p. 101-123, jan.-abr. 2017. DOI: http://dx.doi.org/10.1590/1981.81222017000100006.

Autora para correspondência: Carolina Guedes. Avenida Professor Almeida Prado, 1466. São Paulo, SP, Brasil. CEP 05508-070

(cmguedes@gmail.com).

Recebido em 16/05/2016

Aprovado em 08/09/2016

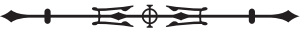




\section{INTRODUÇÃO}

O sítio do Conjunto da Falha está inserido em um contexto de aproximadamente 170 sítios rupestres prospectados, registrados e estudados durante o programa de pesquisas "Pré-história e Paleoambiente da Bacia do Paraná", coordenado pela Prof. ${ }^{a}$ Dr. ${ }^{a}$ Agueda Vilhena Vialou.

Localizada no município de Rondonópolis, no Mato Grosso, a 210 km da capital do estado, Cuiabá (Figura 1), a região da Cidade de Pedra apresenta uma enorme riqueza, tanto no que se trata da quantidade de sítios rupestres, cerâmicos e líticos, quanto ao que se refere à variedade das características geomorfológicas.

De acordo com Silva (2005, p. 13), a região, situada em uma porção da Bacia do rio Vermelho, está inserida:

[...] em uma área de transição entre o planalto e a planície do Pantanal Matogrossense, no contexto do Rio Vermelho, afluente dos rios São Lourenço e Cuiabá, insere-se numa paisagem ruiniforme de morros-testemunhos areníticos, que se estendem por vários quilômetros.
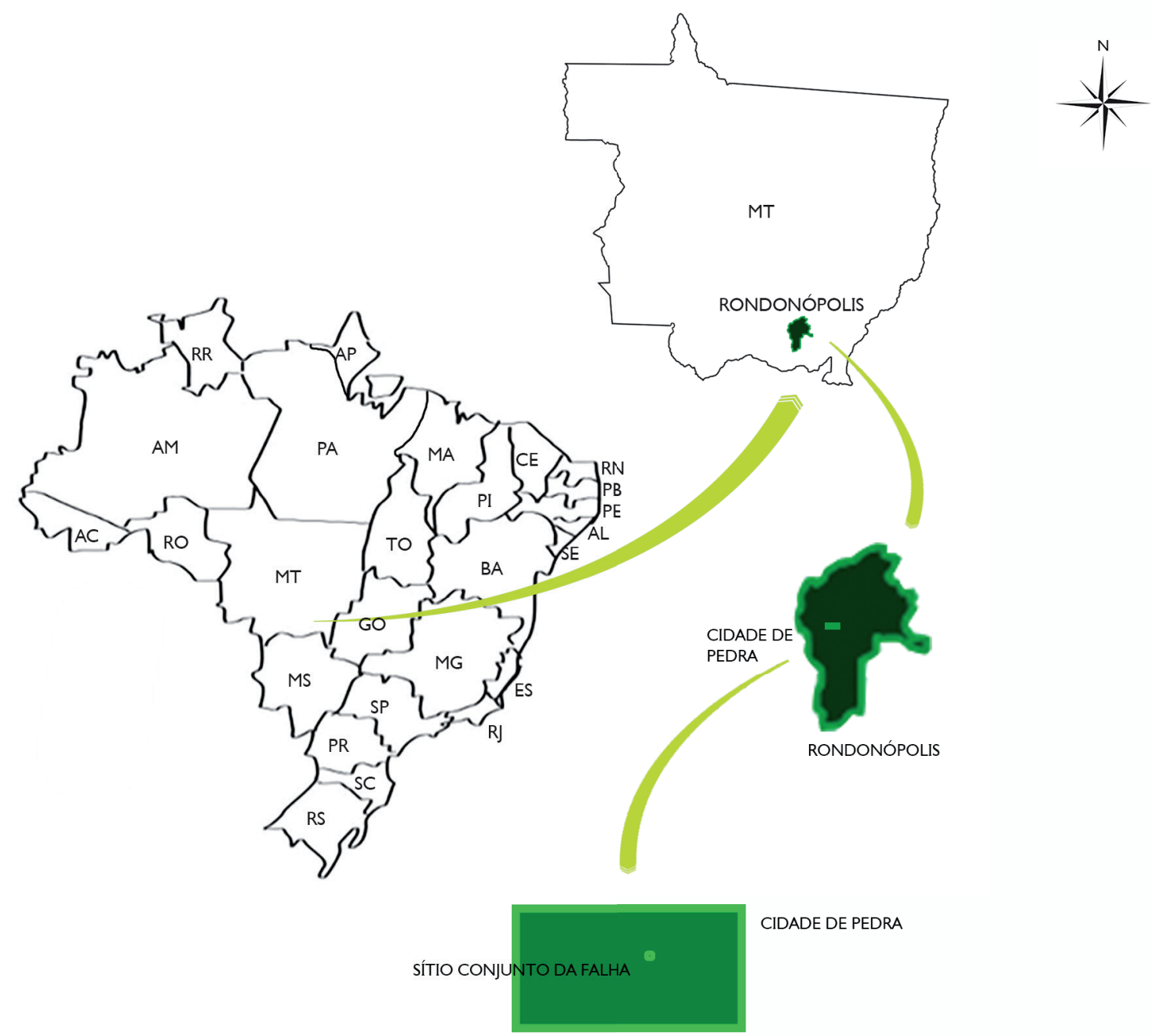

Figura 1. Localização do município de Rondonópolis - Mato Grosso.

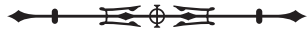


Pela sua característica singular, lembrando edifícios, a região foi nomeada de 'Cidade de Pedra' (Figuras 2A e B).

Este artigo apresenta os resultados de uma articulação entre o corpo teórico da Arqueologia Cognitiva e os dados coletados em campo no sítio da Falha, onde realizamos os últimos trabalhos no ano de 2011, sob a coordenação do Prof. Dr. Denis Vialou, responsável pelo programa "Arte Rupestre", dentro do projeto de pesquisa "Pré-história e Paleoambiente da Bacia do Paraná".

Essa pesquisa foi desenvolvida sob a perspectiva de que as manifestações gráficas registradas nos suportes rochosos pelos homens e mulheres pretéritos é tanto testemunho das crenças e escolhas sociais de um grupo, quanto dos processos cognitivos dos responsáveis por essa forma de comportamento simbólico, processo que demonstra a interrelação entre mente e cultura.

Dentro desse quadro, o suporte foi considerado como parte essencial da construção da mensagem. Uma vez que o suporte rochoso é indissociável do registro gráfico, ele se torna uma categoria semântica, em conjunto com os registros rupestres. De maneira semelhante à utilização da semântica sobre as palavras, em um sítio rupestre seu significado está ligado a um contexto específico.

Assim, a organização de um dispositivo rupestre marca materialmente significados, crenças e escolhas culturais e, nesse sentido, os esquemas iconográficos adquirem significados específicos, em função da sua utilização através da materialização de um determinado tipo de conhecimento, gerado culturalmente e praticado cotidianamente.

Nesse contexto, a semântica representa a porção culturalmente específica na qual a construção simbólica se dá, através da interação dialética entre suporte e os registros gráficos (Sauvet, 1993). O sentido, assim, é criado a partir da relação interna de três elementos: suporte, registro e cultura. Dentro desse quadro, adotamos uma abordagem cognitiva considerando uma compreensão das estruturas que organizam a distribuição dos painéis do sítio da Falha.

Trabalhamos com as propostas de Leroi-Gourhan (1958, 1966) e Sauvet (1993), que, inspirados pela escola estruturalista dos linguistas, propõem uma leitura dos painéis buscando compreender as ligações e as organizações internas estabelecidas entre as diversas unidades gravadas e pintadas e o suporte, ou seja, uma abordagem estruturalista, visando à análise dos grafismos através das relações existentes entre eles e entre os painéis e o suporte.

Para tanto, foram consideradas questões sobre a percepção do ambiente, para gravar e reproduzir conhecimento, e sobre a percepção da seleção temática, para registrar um tipo de "linguagem visual" (Anati, 2003, p. 96). Uma linguagem que instrui simbolicamente, informa e, principalmente, contém sentido. Um significado construído socialmente, elaborado contextualmente, que reflete escolhas, gostos, crenças, formas de organização e

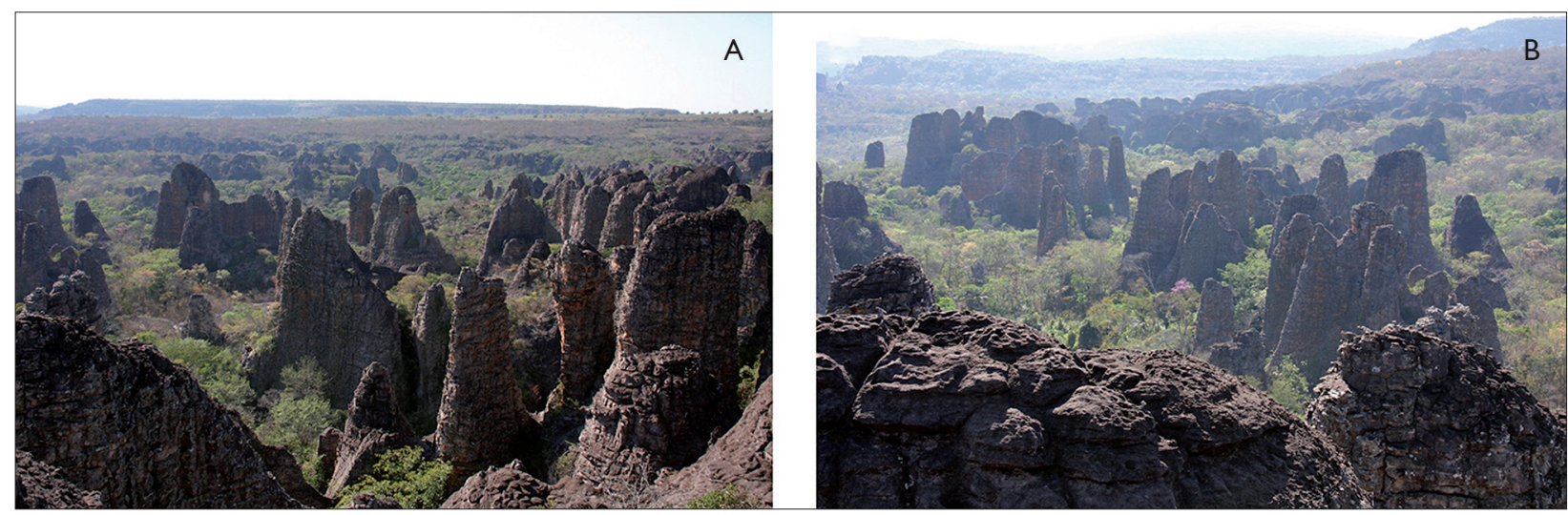

Figura 2. (A) e (B). Paisagem característica da Cidade de Pedra. Fotos: Carolina Guedes, 2011.

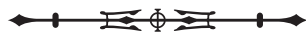


expressão, além de visões de mundo do grupo pretérito responsável por esse tipo de cultura material.

\section{DISCUSSÃO TEÓRICA}

A linguagem visual, materializada e organizada nos dispositivos rupestres, fornece ao pesquisador não somente uma compreensão sobre os traços estilísticos e formais dos registros. Através das construções gráficas presentes nos sítios rupestres, também, temos acesso a ideologias e conceitos imateriais, tais como sistemas de crenças, marcas sociais, organização territorial etc. (Schaafsma, 1985).

Além disso, a arte rupestre proporciona, em certa medida, um vislumbre sobre o nosso aparato cognitivo, ou, em outras palavras, sobre a estrutura básica do pensamento humano. Como o pensar abarca diversas faculdades do intelecto humano, trabalhamos com o conceito de cognição, que, por si só, sugere os diversos modos e artifícios utilizados por nosso cérebro para produzir e reproduzir conhecimento, comunicação e manifestações simbólicas.

De acordo com Segal (1994), pensar cognitivamente objetos de ordem simbólica implica pensar nas ações cognitivas utilizadas na produção de registros gráficos. Implica pensar nas escolhas, codificações, estruturações, classificações, conhecimentos partilhados, enfim, aportes mentais necessários para a produção daqueles objetos.

Dentro desse contexto, conforme Wilson (1999), o fascinante de nossa mente não é só o poder de copiar e recriar imagens de momentos que vivemos e gravamos na nossa memória, mas, fundamentalmente, o poder de dar sentido a essas imagens (Wilson, 1999). O nosso cérebro é diferente do de outros animais, não apenas por possuir uma complexidade própria, mas pela coexistência da mente. Por esse motivo, somos únicos, pela nossa capacidade de simbolizar e dar significado e sensações específicas ao nosso mundo e às nossas lembranças.

Compreender esses elementos é importante para avaliarmos as construções simbólicas dos sítios rupestres, uma vez que nos dá base para compreendermos a estrutura de funcionamento do processo criativo.
Portanto, trabalhamos com uma categoria material que se apresenta para nós através de construções simbólicas. São manifestações inteiramente abstratas, que carregam significados culturais. Trata-se de construções estruturadas de discursos socialmente construídos e praticados, que, de acordo com Pinker (2007), são uma maneira de conectar sentido e forma (Pinker, 2007), baseada em tradições e em culturas.

Dentro desse quadro, a abordagem estruturalista de Leroi-Gourhan $(1958,1966)$ é, em parte, mantida aqui. O referido pré-historiador, seguindo a tradição de análises estruturalistas das grutas paleolíticas da Europa inaugurada por Raphaël (1945), apresentou uma nova maneira de compreender e analisar a arte parietal. Apesar de sua proposta interpretativa sobre a presença de uma estrutura dualista, principalmente em função da dialética masculino/ feminino ter sido há muito criticada e revisada, as propostas advindas de seus métodos ainda inspiram muitas pesquisas realizadas atualmente.

É importante salientar que essas construções devem ser analisadas levando em consideração os contextos em que os sítios se encontram. Ou seja, avaliar o processo de construção e formação de um sítio rupestre, avaliar a sua construção simbólica, deve necessariamente considerar o contexto no qual ele está inserido, uma vez que estamos imersos em um mundo construído por pensamentos simbólicos, culturalmente significativos.

Nesse viés, consideramos a existência de uma estrutura particular, inerente à construção de cada sítio, responsável pela organização simbólica e pela criação de sentido através de associações específicas. Em um sítio rupestre, a natureza (humana e meio ambiente) e a cultura se encontram; elas coexistem e o sentido é criado em uma conjunção dessas variantes. Tais conjunções são produtos únicos da interação entre cérebro e a cultura (Lewis-Williams; Pearce, 2005).

Em conjunção com a abordagem estruturalista, utilizamos as propostas da Arqueologia Cognitiva nas análises do conjunto da Falha. Renfrew (1995, p. 3) definiu 
a Arqueologia Cognitiva como "o estudo das formas pretéritas de pensamento inferidas a partir dos vestígios materiais". Em linhas gerais, a Arqueologia Cognitiva propõe ser possível compreender processos imateriais responsáveis pela criação de vestígios materiais.

Surgindo dos debates entre os processualistas e pós-processualistas, a Arqueologia Cognitiva desenvolveu ferramentas de análise e meios de inferências para a compreensão dos diversos aspectos do comportamento humano, entre eles as manifestações simbólicas.

A proposta foca sobretudo na compreensão do processo pelo qual as manifestações sociais foram construídas. É a diferença entre a procura do significado 'o que?' e a compreensão do comportamento 'como?'; "para o arqueólogo cognitivo-processual, é suficiente obter conhecimentos sobre como as mentes das comunidades em questão trabalhavam e na maneira a qual esse trabalho moldou suas ações" (Renfrew, 1995, p. 6).

A proposta analítica ora utilizada se deu através da interpretação não baseada 'em que' os homens e mulheres pretéritos pensaram, mas, diferentemente, baseada em 'como' eles expressaram seus pensamentos e suas ideologias.

Ao se preocupar com esses problemas, a Arqueologia Cognitiva tenta unir as categorias que, ao longo dos tempos, foram separadas, notadamente a relação entre homem e cultura material, tentando criar formas de análise que permitam ao arqueólogo acessar os processos de construção dos comportamentos sociais. Nessa linha, é possível inferir, a partir dos vestígios materiais, as ações do comportamento de grupos sociais na produção da cultura material.

A composição total de um vestígio arqueológico está imbuída de uma carga de ações, escolhas, pensamentos e tradições. Para compreender essas ações, utilizamos, na análise do sítio rupestre da Falha, dois conceitos analíticos: percepção e escolha. É através da compreensão sobre a articulação entre forma, organização das unidades e suporte que podemos compreender a organização simbólica e, portanto, cultural dos dispositivos rupestres.

\section{O SÍTIO DA FALHA DENTRO DO CONTEXTO DA CIDADE DE PEDRA}

Nas proximidades da Falha se encontram três sítios rupestres. Um ao sul, a uma distância de pouco mais de uma dezena de metros, chamado sítio Cogumelo, que contém apenas um sinal em forma de cacho simples e alguns traços vestigiais.

O segundo sítio, Alvorada, está localizado a uma centena de metros ao norte do sítio da Falha, e oferece uma sequência de painéis, com grande quantidade de sinais e de raras representações figurativas esquemáticas (animais). Grandes sinais com preenchimentos lineares e pontilhados e outros circulares evocam fortemente os presentes no Painel 5 do sítio da Falha, situado precisamente sobre o flanco orientado em direção ao sítio Alvorada. As ligações gráfico-simbólicas entre esses painéis de sinais vermelhos complexos são diretas.

A uma distância de aproximadamente 200 metros do sítio da Falha, em direção ao sudoeste, encontra-se um terceiro sítio, Abelha, em uma pequena cavidade baixa, que conserva uma dezena de representações, nas quais duas remetem, novamente, ao sítio da Falha: em primeiro lugar, um sinal em forma de 8 alongado; depois, uma pintura de um animal em vista superior que pode ser comparado ao 'lagarto' pintado sobre o teto baixo de uma abertura em fenda sobre o flanco oeste do sítio da Falha, precisamente aquele orientado em direção ao sítio rupestre Abelha.

As conexões simbólicas entre os quatro sítios vizinhos são evidentes tanto sobre o plano de escolha temática, quanto sobre o plano de implantações orientadas a direções recíprocas. Um microterritório rupestre original é assim constituído.

Dentro do contexto da Cidade de Pedra, que se estende sobre $350 \mathrm{~km}^{2}$, o sítio da Falha e seus satélites se situam sobre um limite geográfico bem perceptível, separando a microbacia do abrigo de Ferraz Egreja, a leste, e a microbacia central da Cidade de Pedra, a oeste (Figura 3). 


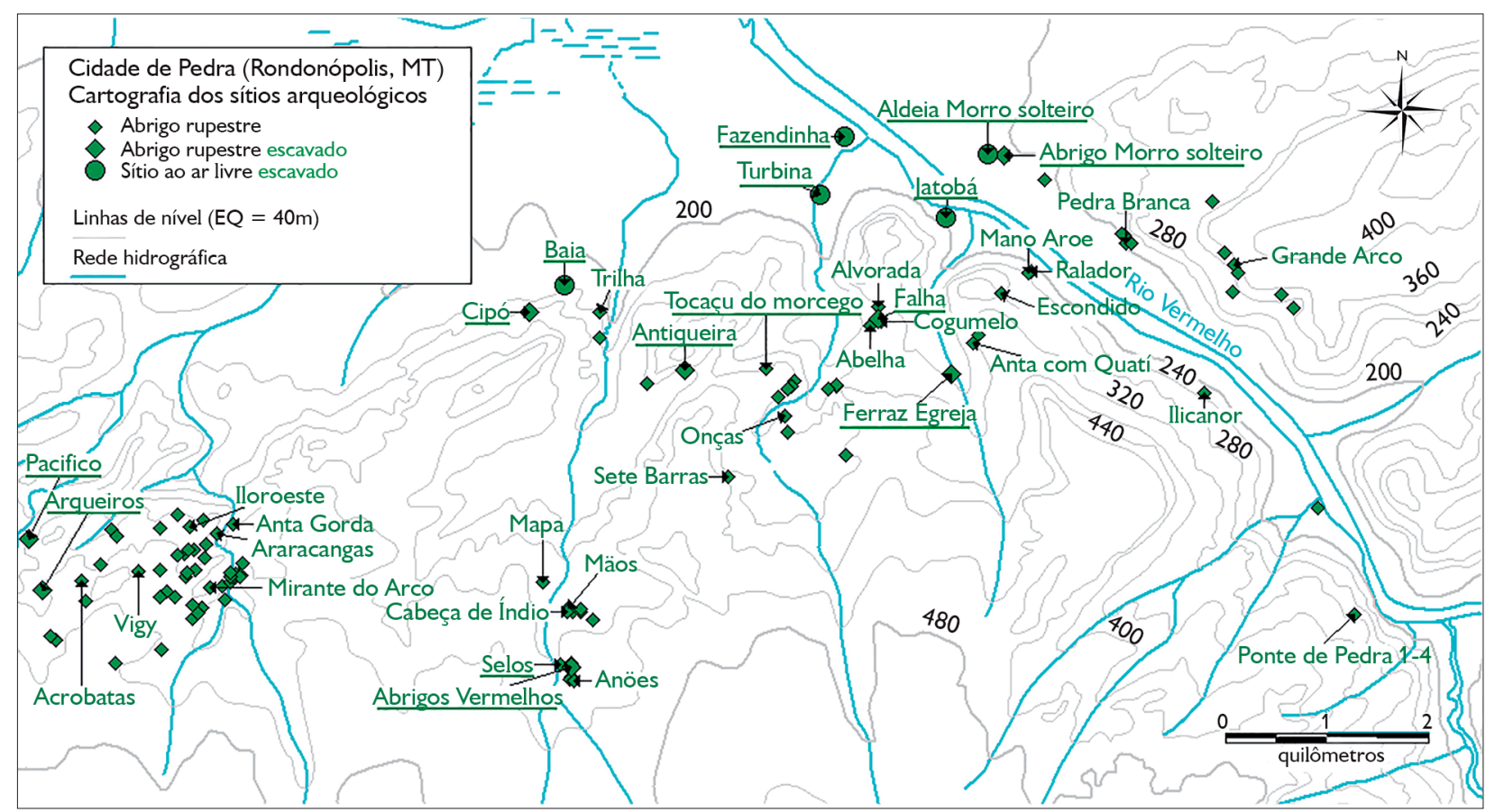

Figura 3. Cartografia dos sítios arqueológicos na região da Cidade de Pedra. Mapa: Eduardo Vilhena de Toledo; Jean-Roch Houllier, 2013.

sítio da Falha aparece ao topo no horizonte, desde a zona mais elevada a oeste de relevos areníticos, bordeando essa zona central da Cidade de Pedra a partir da borda igualmente elevada da chapada, à margem direita do rio Vermelho.

As representações gráficas abstratas complexas (os sinais) pertencentes aos dez sítios rupestres da microbacia central são globalmente diferentes das encontradas no sítio da Falha e seus satélites. Os mais de quarenta sítios rupestres, situados mais a oeste da região, oferecem, em sua maioria, sinais complexos diferentes daqueles da microbacia central, compreendendo os do sítio da Falha e associados, os da microbacia de Ferraz Egreja e os sítios rupestres próximos ao rio Vermelho.

Na margem esquerda, próximo ao rio, o sítio Mano Aroe conserva um dispositivo parietal notável, denso, quase exclusivamente composto de sinais, alguns simples - e portanto correntes - e outros complexos. Trata-se notadamente de sinais circulares, ovalados, com preenchimentos lineares elaborados.
A comparação entre ele, o sítio Alvorada e o Painel 5 do sítio da Falha evidencia parentescos simbólicos. Trata-se de diversos sinais complexos, igualmente presentes no abrigo Ferraz Egreja (a menos de $2 \mathrm{~km}$ à leste da Falha), e também dos sinais complexos do Morro Solteiro, à margem direita do rio Vermelho.

Esse imenso morro, próximo ao bordo da chapada, é composto de diversos locus rupestres, onde os painéis e as longas sequências lineares reúnem principalmente os sinais complexos, em grande parte aparentados àqueles da Falha-Alvorada, Ferraz Egreja e Mano Aroe.

A estruturação espacial em diversos locus rupestres do Morro Solteiro oferece um paralelismo com a Falha. Trata-se igualmente de uma integração pensada e construída de dados topográficos e morfológicos parietais na construção simbólica do sítio, em toda a sua amplitude. Como na Falha, o deslocamento e o movimento do criador, e depois do observador, são indispensáveis para a percepção e a leitura interpretativa das representações.

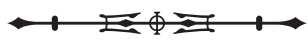


O dispositivo parietal assim dividido se revela em uma dimensão diacrônica, e não sobre uma instantaneidade de um olhar apressado.

Vemos, assim, como o sítio da Falha se insere e se relaciona com outros sítios em diversos aspectos, na rica iconografia rupestre da região da Cidade de Pedra: um mosaico de territórios rupestres estreitamente correlacionados com as diferentes paisagens da região, divididas entre os grandes picos dos relevos, das cavidades dos múltiplos abrigos difíceis de cruzar e percorrer e entre o eixo do rio de uma circulação fácil e aberta ao sul, sobre o planalto, em direção a oeste para a depressão do Pantanal.

\section{PESQUISAS ANTERIORES SOBRE O SÍTIO DA FALHA}

As primeiras informações sobre o sítio rupestre da Falha são provenientes dos relatórios ${ }^{1}$ das campanhas inseridas no projeto de pesquisa anteriormente citado, e dos trabalhos realizados por Keroualin (1988, 2006). As informações publicadas sobre esse sítio (Keroualin, 2006) tratam de uma análise do aspecto formal dos registros rupestres e da construção simbólica dos painéis, avaliando as relações entre a variabilidade/unidade das expressões gráficas.

Em sua abordagem, Keroualin (2006, p. 71) trabalha com um "estudo detalhado das figuras", considerando vários eixos de análises, como temas, técnicas picturais e dados tipológicos. $\bigcirc$ autor apresenta uma abordagem sistemática das unidades gráficas através de oito quadros de entrada dupla, gerando dados para discussão sobre as particularidades e a variabilidade das formas e técnicas utilizadas na construção dos diversos elementos gráficos, sistematizando em categorias os diversos registros rupestres presentes no sítio.

De maneira geral, as propostas de análises de Keroualin (2006) se assemelham às apresentadas neste artigo. Porém, enquanto no presente artigo focamos na apresentação integral dos painéis rupestres como elementos da nossa análise, Keroualin (2006) focou no aspecto quantitativo das unidades gráficas.

Em ambos os casos, a proposta geral das análises foi a compreensão sistemática sobre a construção simbólica dos diferentes painéis do sítio da Falha. Independentemente se a observação se apóia em uma análise sobre o "impacto visual" (Keroualin, 2006, p. 74) da organização das unidades gráficas, ou na relação entre o conjunto gráfico e seu suporte, ambas as propostas visaram a compreensão sobre a construção simbólica do sítio em sua totalidade.

Podemos afirmar, com base na publicação de Keroualin (2006), nas leituras dos relatórios de campo e nas nossas visitas ao sítio, que o Conjunto da Falha engloba importantes traços culturais regionalmente específicos, alternando a elaboração de sinais complexos - e, portanto, indicadores culturais - com sinais simples e, portanto, universais. Notamos que essa universalidade se refere tão somente ao aspecto formal. Em outras palavras, a forma se repete, não o significado.

Trabalhamos aqui com duas descrições gerais dos grafismos, os chamados 'simples' e os 'complexos'. Designamos de 'simples', sobretudo, os grafismos construídos com poucos traços, como é o caso de círculos, pontos e bastonetes, normalmente vazios ou com preenchimentos pouco elaborados. Já os grafismos 'complexos' apresentam maior elaboração visual, com preenchimentos mais complexos ou agrupamentos mais elaborados, por exemplo o agrupamento de pontos do Painel 7, descrito no tópico seguinte.

\section{ELEMENTOS DA CONSTRUÇÃO GRÁFICA}

O sítio em questão é denominado 'Conjunto' da Falha por apresentar um total de sete painéis distintos, distribuídos por diversas formações areníticas. Trata-se de diversos afloramentos distintos pela sua formação topográfica.

Os painéis estão localizados em diferentes porções desses afloramentos, de forma única, seja pela localização,

\footnotetext{
Não publicados.
}

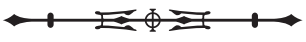


seja pela temática geral tratada. Consideramos aqui que a própria topografia do sítio orientou de alguma forma as construções simbólicas dos painéis rupestres.

Dentre os muitos afloramentos presentes nessa área, um total de quatro foi utilizado como suporte para os painéis rupestres. As características dos suportes variam morfologicamente, apresentando especificidades.

$\bigcirc$ primeiro suporte, um grande afloramento arenítico, possui área homogênea na porção central, proporcionando um local conveniente para a realização das pinturas. Com uma superfície no geral irregular, a área selecionada se apresenta de maneira homogênea, porém com presença de desplacamentos.

○ segundo suporte, onde estão dispostos os Painéis 2, 3 e 4, é um grande afloramento de aproximadamente 15 m de extensão. Nele, cada painel ocupa um local com características próprias, no que se refere à localização (teto/parede) e ao espaço utilizado (escondido ou em plena vista).

Enquanto os Painéis 2 e 4 estão dispostos nas laterais desse grande afloramento, com paredes regulares e com nichos de relevo relativamente homogêneos, o Painel 3 foi disposto sobre o teto em uma abertura a 1,70 $\mathrm{m}$ do solo. Ainda que existam alguns desplacamentos e pequenas variações no relevo natural do suporte, de

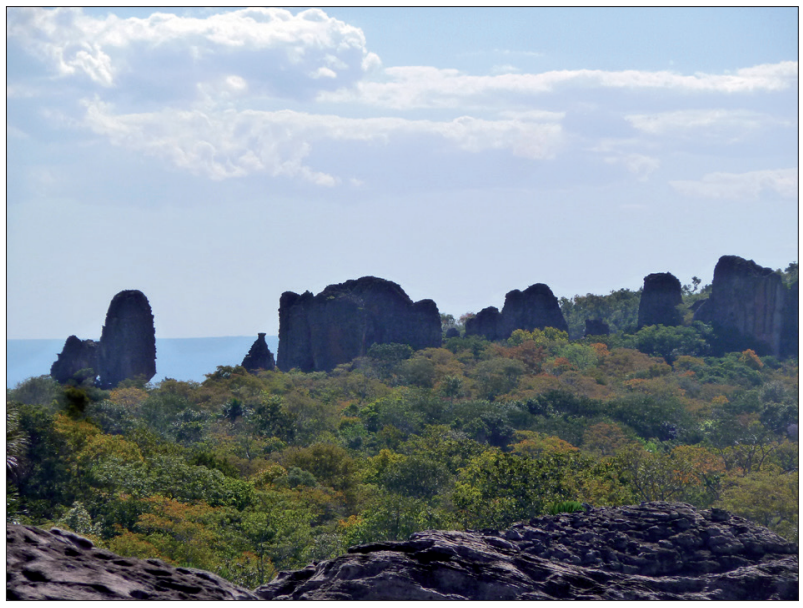

Figura 4. Vista geral dos afloramentos rochosos que compõem o Conjunto da Falha. Foto: Patrick Paillet, 2011. maneira geral a área ocupada pelo painel apresenta-se bastante regular.

$\bigcirc$ Painel 5 foi disposto sobre o teto de uma grande fenda, localizada no alto do afloramento, a uma distância de $6 \mathrm{~m}$ do solo, com extensão total de 7,10 m. A parte interna da abertura apresenta um declive suave até o ponto em que o teto e o chão se unem. Na parte mais externa, a abertura mede aproximadamente 1,80 m. Todas as pinturas estão localizadas sobre o teto, que, de maneira geral, apresenta homogeneidade no relevo.

Painel de número 6 está localizado sobre parede reclinada, em uma abertura de um grande afloramento, a uma distância de 0,60 m do solo. Enquanto sua fachada externa é bastante heterogênea, o relevo da parede se apresenta bem liso e regular.

O sétimo e último painel está localizado na parte mais afastada de todo o conjunto. Localizado sobre o teto, em baixa abertura de um liso afloramento arenítico, sua altura máxima atinge apenas $1,05 \mathrm{~m}$.

$\bigcirc$ conjunto de afloramentos apresenta grande destaque na paisagem, podendo ser observado de longas distâncias e a partir de outros sítios da região da Cidade de Pedra (Figura 4). Um dos seus grandes morros é separado por uma lacuna, sendo, por esse motivo, denominado de Falha (Figura 5).

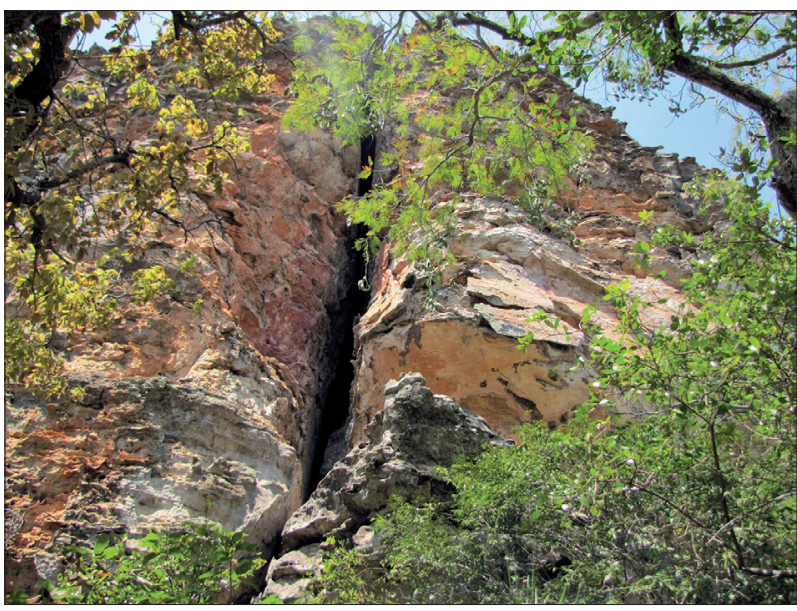

Figura 5. Detalhe da falha do afloramento que deu o nome ao sítio. Foto: Carolina Guedes, 2011

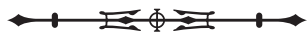


Em função da vegetação circundante, o acesso a esse painel é feito por um caminho aberto recentemente, o que permite uma observação do sítio em fases consecutivas e organizadas, ou seja, o primeiro painel está situado nas proximidades desse caminho atual. Esse fato foi crucial também para a organização numérica dos painéis, sendo o Painel de número 1 (Figura 6) o mais próximo à entrada atual e o de número 7 o mais afastado.

As pinturas em vermelho dominam quase totalmente a paleta de cores, com nuanças no tom, devido ao desgaste natural dos registros. No entanto, alguns tons violáceos e marrom-amarelados estão presentes em algumas unidades, implicando uma escolha deliberada do autor ou autores.

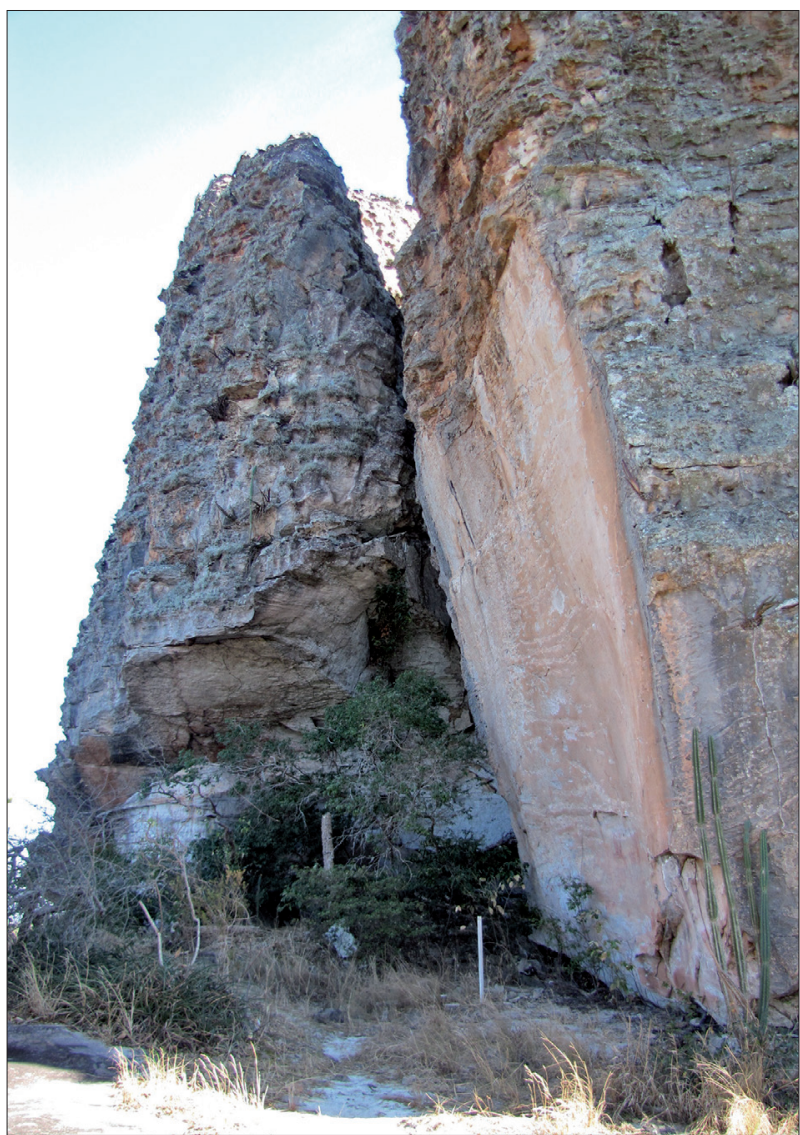

Figura 6. Vista geral do painel 1 à direita. Nota-se ao fundo um segundo afloramento onde se localizam os painéis 2 e 3. Foto: Carolina Guedes, 2011.
Como na maioria dos sítios da região, no sítio da Falha como um todo há presença de grande número de registros geométricos simples, os sinais, representados principalmente pelo ponto, círculo e traço e suas diversas declinações, como retângulos, com diversas formas de preenchimento, traços em paralelo, que formam novas unidades gráficas.

\section{AS REPRESENTAÇÕES RUPESTRES}

Com um total de 83 unidades gráficas, o Conjunto da Falha é um sítio extremamente complexo no que se refere à organização e à criação dos painéis e das unidades, bem como aos locais e dispositivos utilizados. Composto em sua maioria por registros não figurativos, a simplicidade de algumas unidades contrasta com a complexidade exibida na distribuição e associação dos registros.

\section{PAINEL 1}

O primeiro painel está situado em um paredão, onde as pinturas estão dispostas em uma altura máxima de 3 metros e mínima de 30 centímetros do solo. Esse dispositivo apresenta pinturas figurativas e não figurativas, dentre elas, figuras geométricas circulares, retas e preenchimentos. $\bigcirc$ primeiro painel é o que mais apresenta pinturas figurativas, alguns animais, como cervídeos e borboleta, e figuras humanas esquemáticas. Ainda que algumas unidades sejam vestigiais, podemos perceber uma temática bem dividida entre os figurativos e não figurativos (Figuras 6, 7 e 8).

No prolongamento da parede alta e retilínea do Painel 1, o afloramento se alarga. À direita, abre-se verticalmente a falha; à esquerda, se encontra um recanto abrigado, conformado por uma parede inclinada na qual estão desenhados alguns motivos. Sobre a superfície muito inclinada, pouco visível e de difícil acesso do grande rochedo localizado no centro desse recanto, encontra-se uma pintura em cor amarelo-marrom (por volta de 30-40 cm de altura), que evoca um animal com duas longas orelhas desenhadas sobre a cabeça, pescoço longo, corpo filiforme e grandes patas (Figuras 9 e 10).

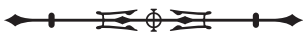




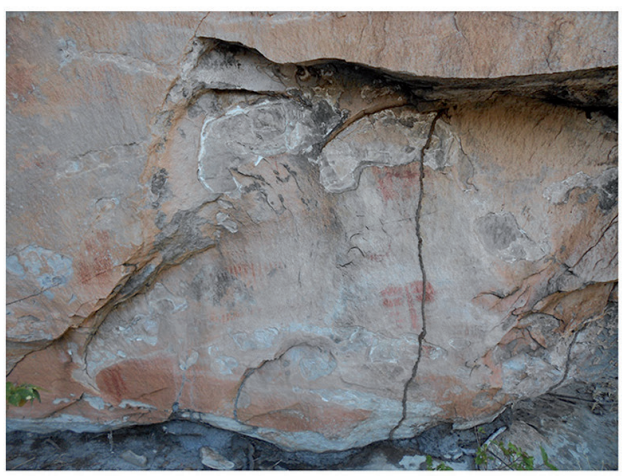

A
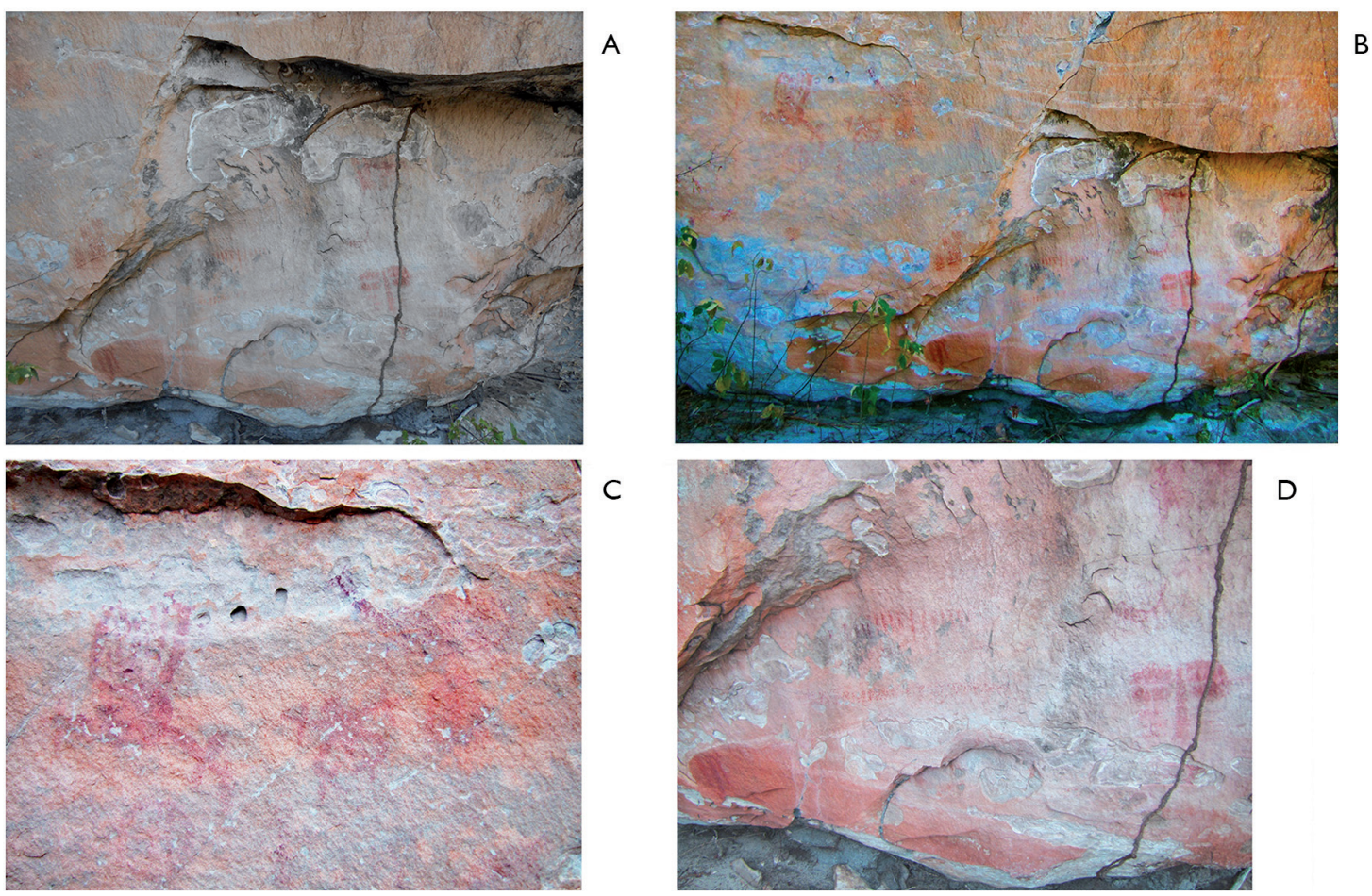

C

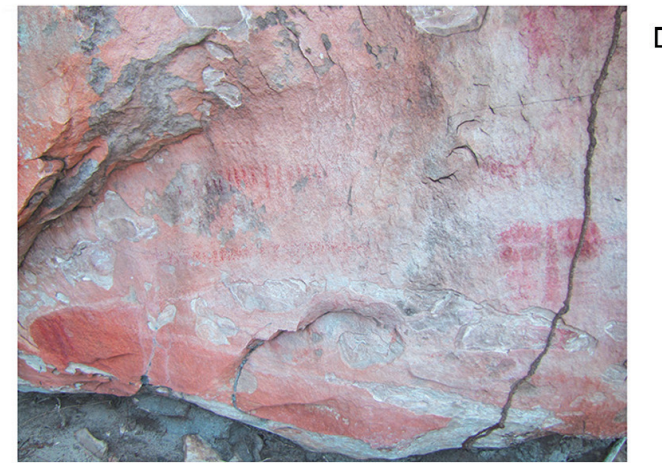

$\mathrm{D}$

Figura 7. Detalhe do Painel 1 (A) e (B) Imagem geral do painel. (C) e (D) Imagens aproximadas do painel rupestre. Nota-se as pinturas de forma vestigial em tom vermelho na parte inferior do dispositivo. Imagem manipulada digitalmente - Photoshop. Foto: Carolina Guedes, 2011.

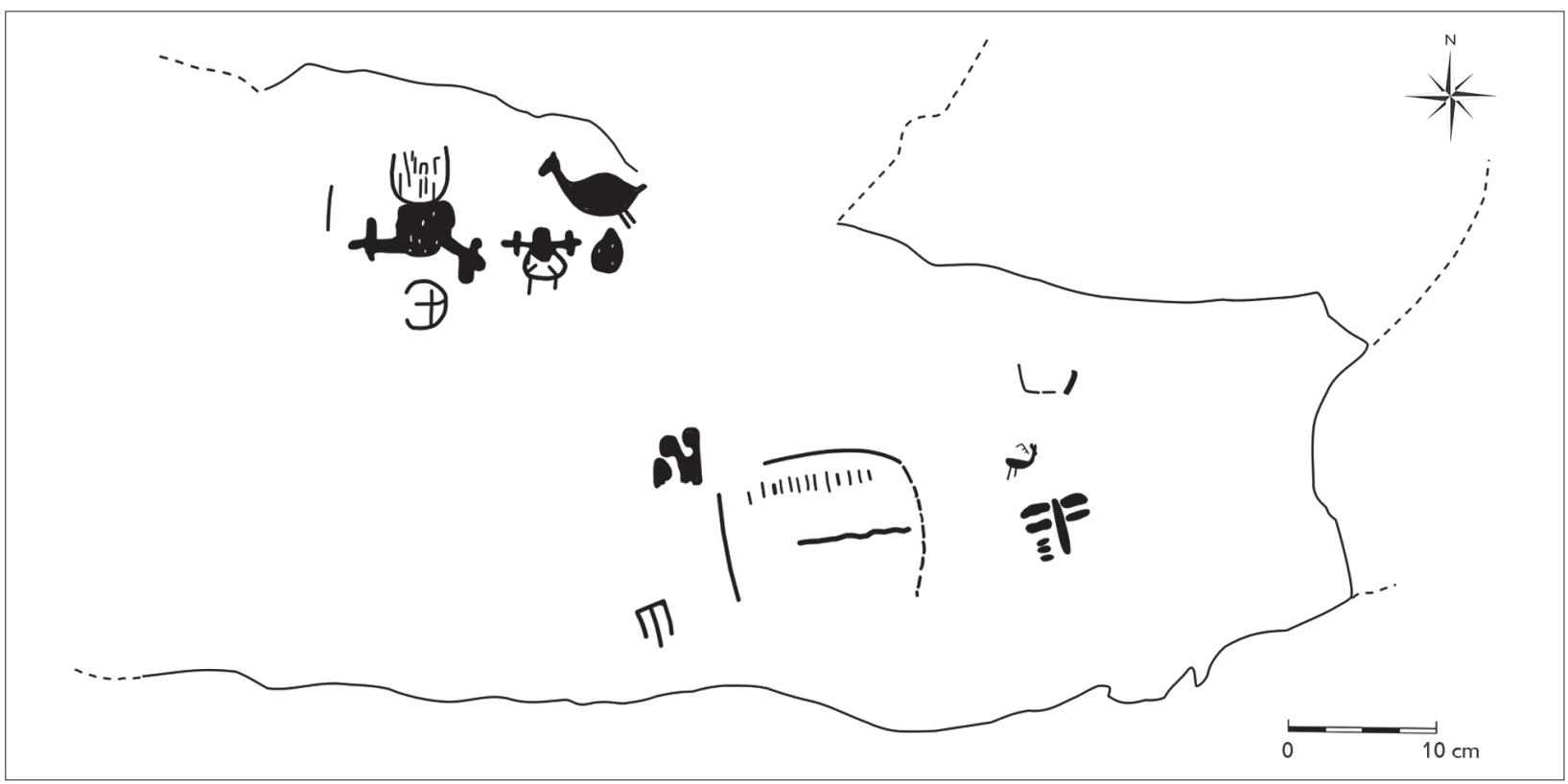

Figura 8. Painel 1 - Plano diretor escalado. Imagem vetorizada: Carolina Guedes, 2011.

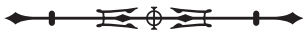




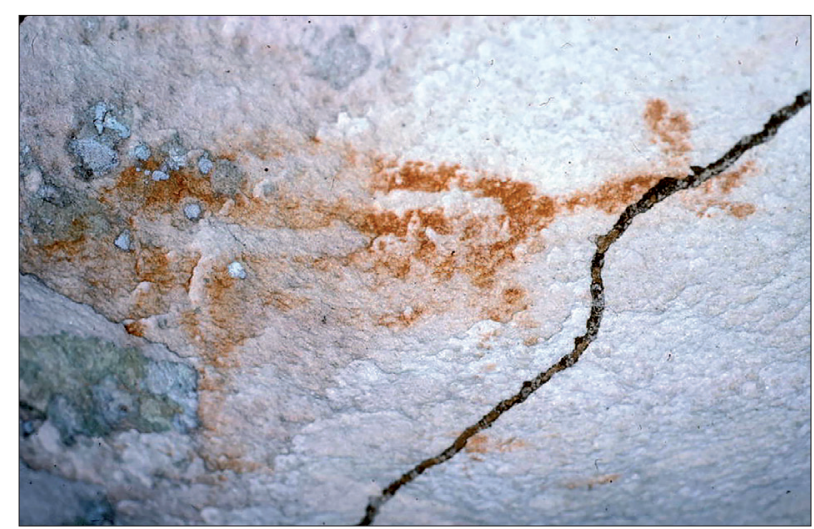

Figura 9. Detalhe animal isolado. Foto: Denis Vialou, 1997.

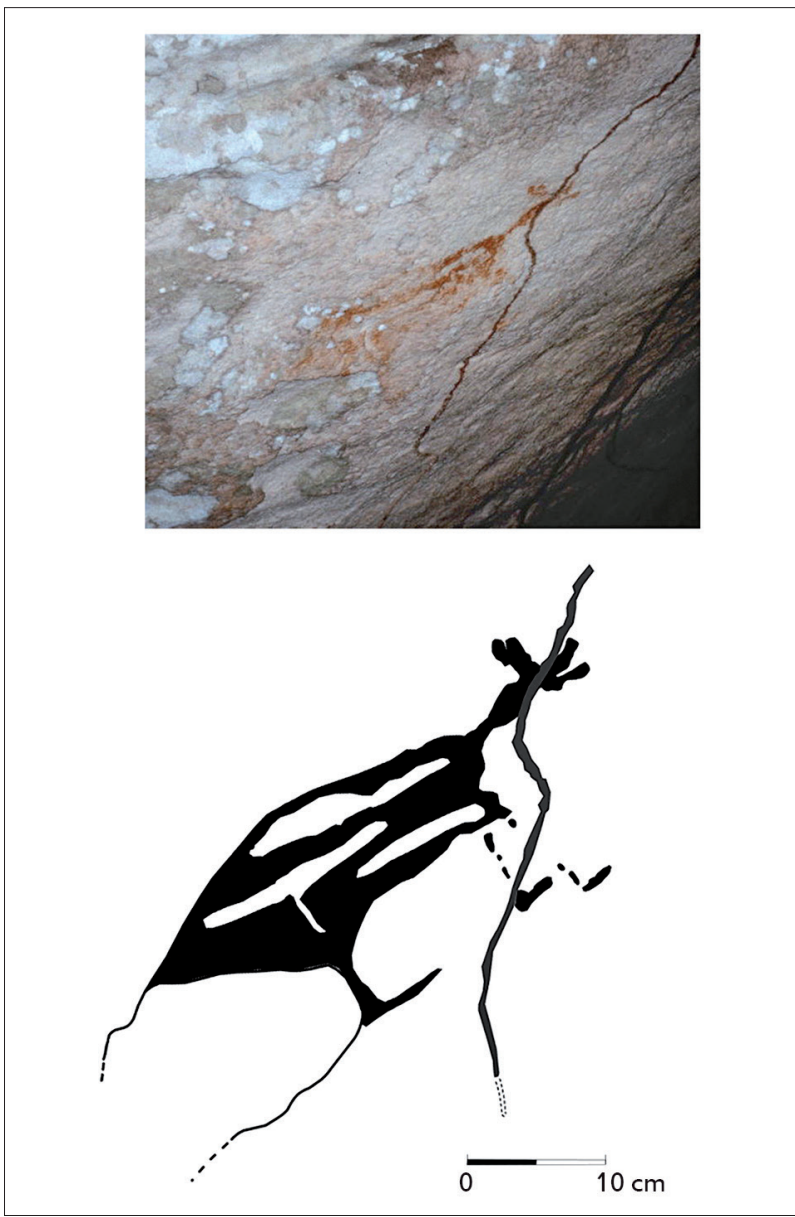

Figura 10. Detalhe animal isolado: Nota-se à esquerda da imagem vetorizada uma falha decorrente da preservação do suporte rochoso deixando a pintura incompleta. Vetorização digital realizada através de software livre Inkscape. Imagem vetorizada: Carolina Guedes 2016; Foto: Denis Vialou, 1997.
Sob a figura, ocorrem manchas de escorrimento e de resíduos de pigmentos, dificultando a leitura. Essa figura fantástica escapa a toda tentativa de identificação naturalista. Além disso, ela se encontra isolada e, de alguma forma, escondida, contrariamente às representações dos Painéis 1 e 2 .

\section{PAINEL 2}

O segundo painel está localizado em uma porção inclinada do segundo afloramento rochoso, a uma distância de aproximadamente 1,70 metros do solo (Figura 11). Esse conjunto apresenta uma composição totalmente diferente do primeiro, ainda que esteja a poucos metros do Painel 1. A singularidade das unidades pintadas é bastante característica, pois, apesar de seu número reduzido; são figuras bem estruturadas e podem se encaixar na categoria de motivos proposta por Vialou (2006). Trata-se de elementos verdadeiramente únicos nesse sítio (Figuras 12 e 13).

\section{PAINEL 3}

O terceiro conjunto, de pouca visibilidade à distancia, encontra-se sob o teto do mesmo afloramento apresentado anteriormente (Figura 14). Nesse painel rupestre, pode-se perceber a presença de elementos geométricos bastante singulares, como a composição sinuosa evidente no plano diretor apresentado (Figura 15).

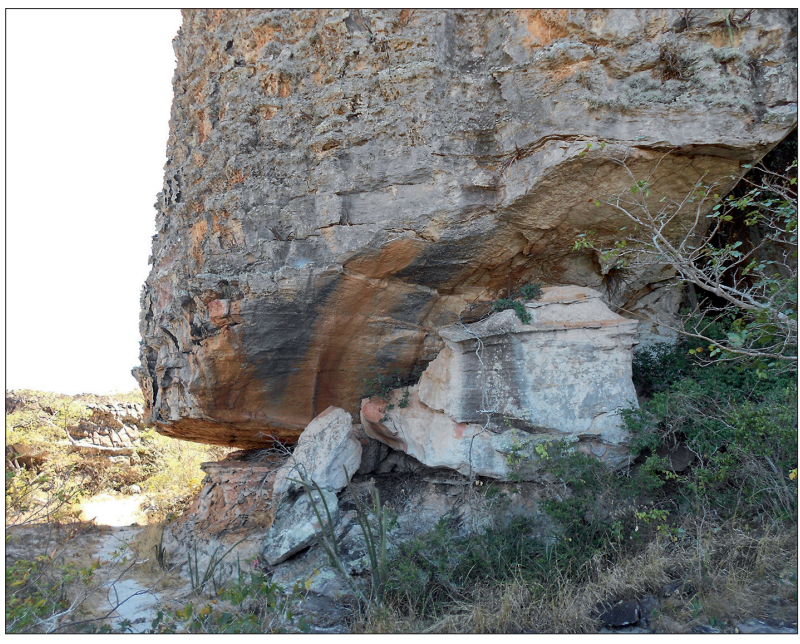

Figura 11. Vista geral do painel 2. Foto: Carolina Guedes, 2011.

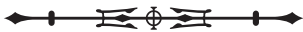




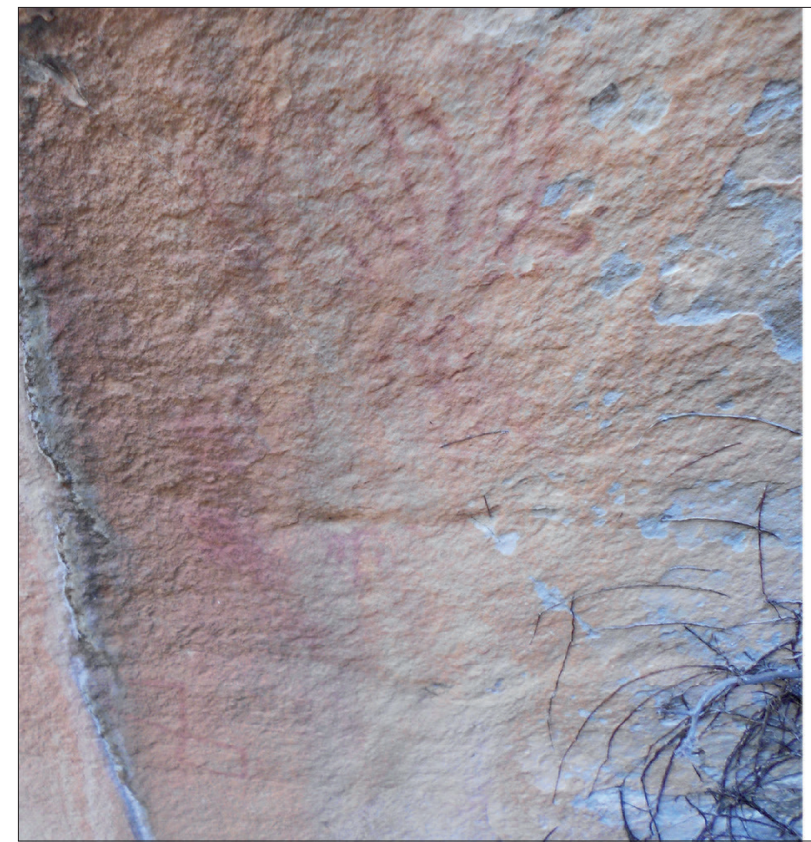

A

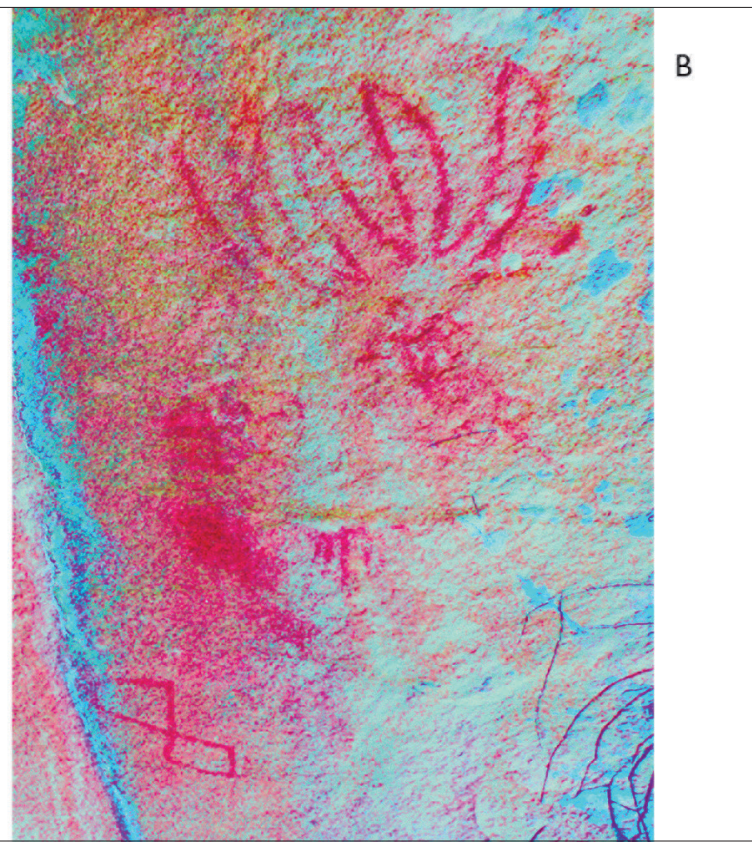

Figura 12: Pinturas figurativas e não figurativas. A imagem (A) mostra o grafismo de forma vestigial, como observado em campo. A imagem (B) mostra o grafismo após o tratamento através do software DStretch (LRE). Foto: Carolina Guedes, 2011.

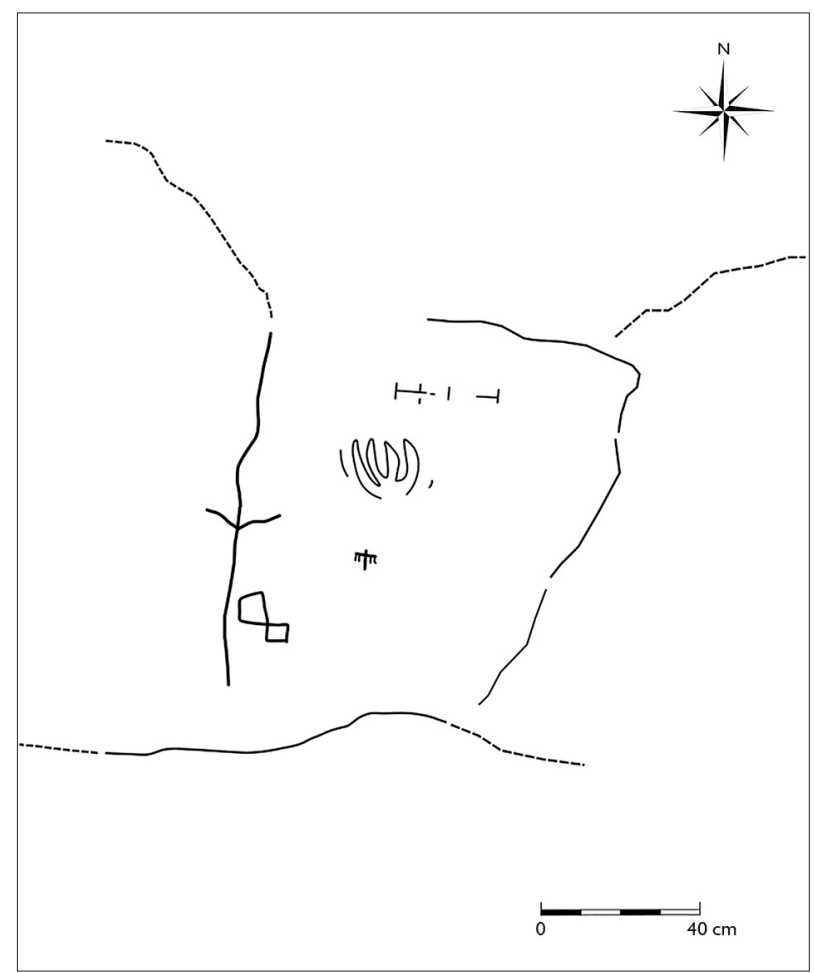

Figura 13. Painel 2 - Plano diretor escalado. Imagem vetorizada: Carolina Guedes, 2011.

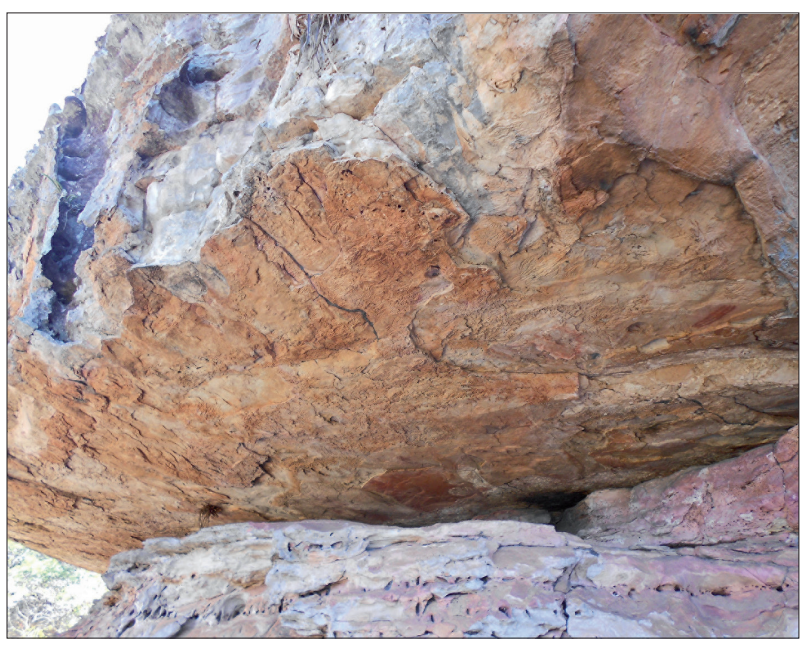

Figura 14. Vista geral do painel 3. Foto: Carolina Guedes, 2011.

As pinturas desse painel encontram-se bastante vestigiais, excetuando-se o lagarto (Figuras 15B e 16), muito bem conservado, apesar de demonstrar alguns sinais de deterioração. Sua cor violácea é indício importante da construção simbólica do painel, uma vez que a maioria das unidades são de tons vermelhos.

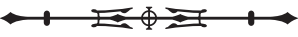



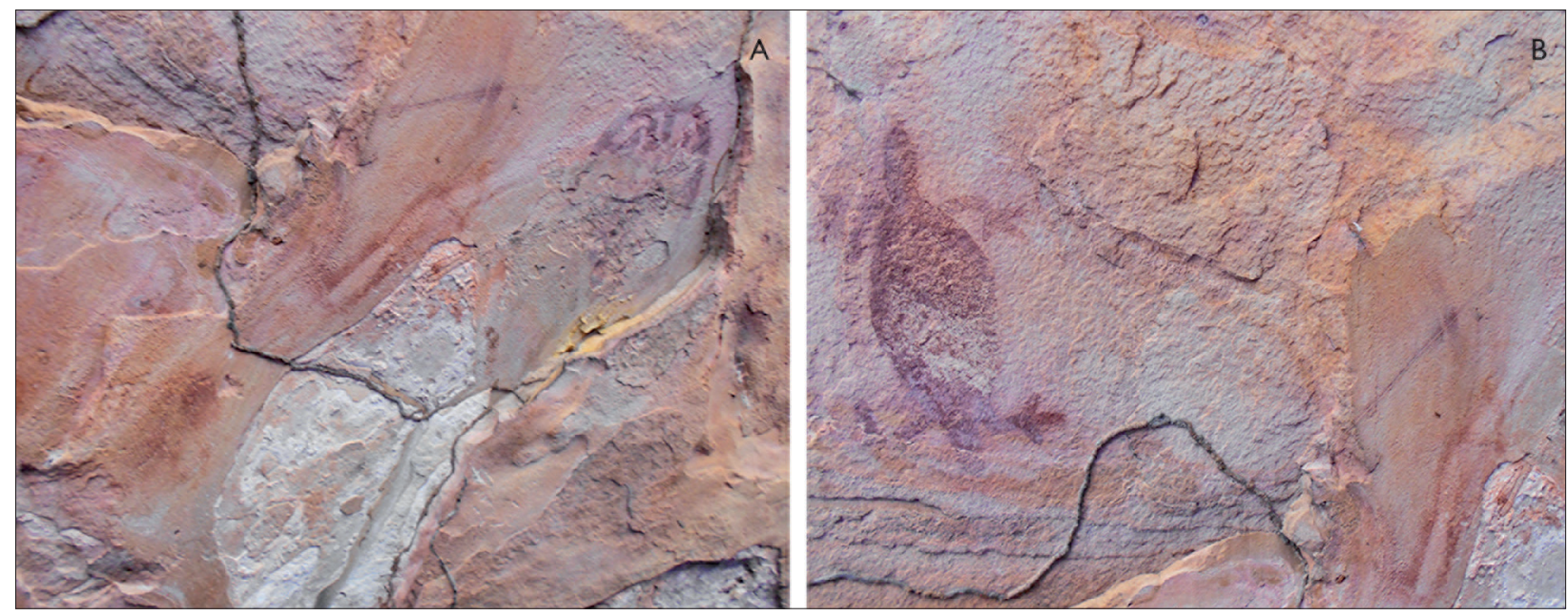

Figura 15. Detalhe do painel 3. (A) pintura não-figurativa em tom violáceo. (B) Detalhe de unidade gráfica. Elemento figurativo em tom violáceo. Fotos: Carolina Guedes, 2011.

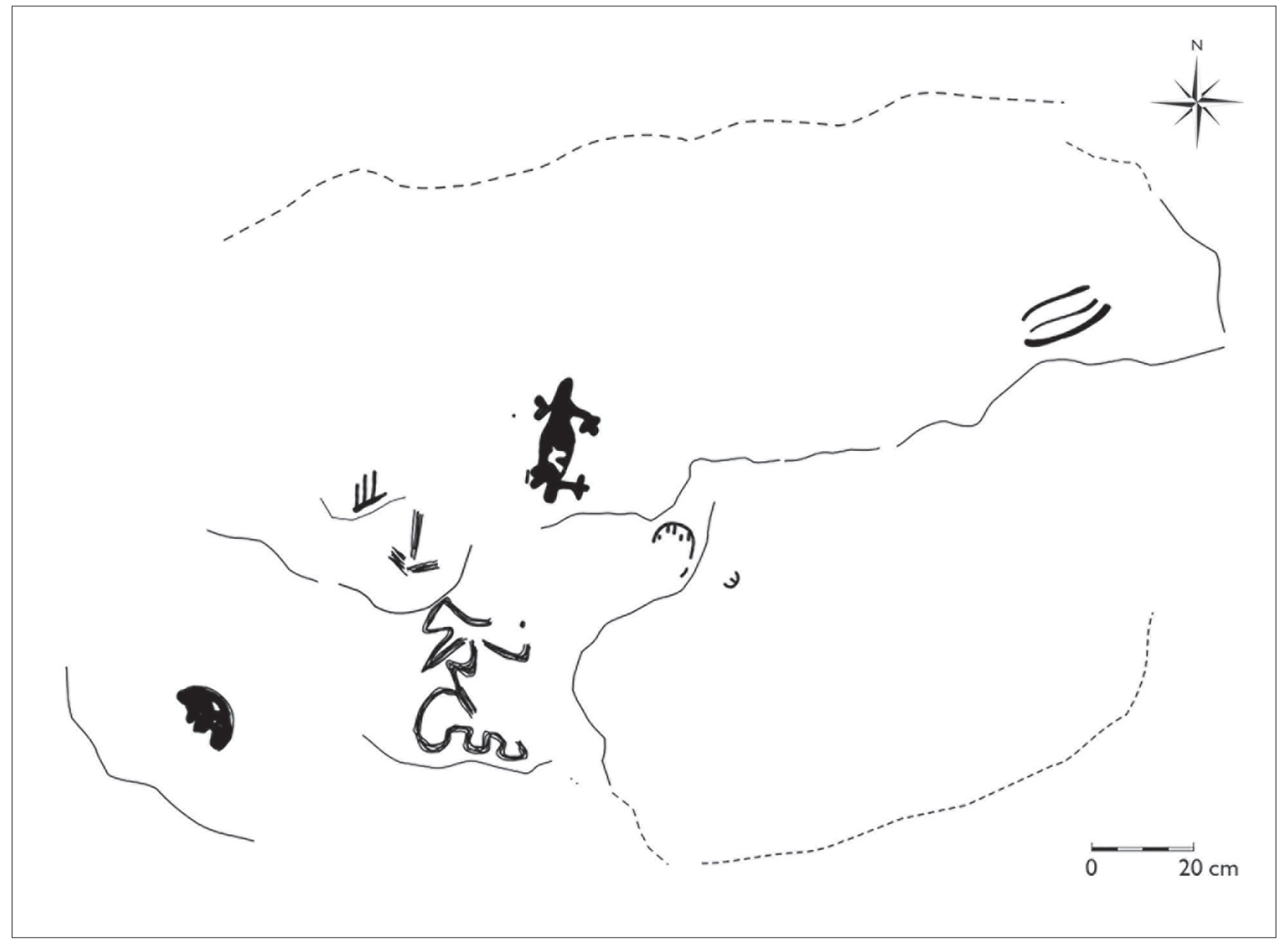

Figura 16. Plano diretor escalado com a localização das pinturas: figurativos e não-figurativos. Imagem vetorizada: Carolina Guedes, 2011.

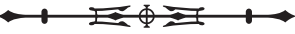




\section{PAINEL 4}

O quarto painel está localizado em uma área de grande visibilidade, porém seus traços são apenas vestigiais. Foram realizados com bastões de hematita, diretamente sobre a rocha, técnica conhecida como crayon (Figuras 17 e 18). Trata-se de duas composições, distantes apenas um metro, realizadas com a mesma técnica de desenho. São sinais compostos de traços horizontais e verticais (Figura 19).

\section{PAINEL 5}

No quinto conjunto, localizado em uma abertura a 6 metros do solo (Figura 20), os registros estão dispostos sobre o teto, contendo uma dispersão espacial que ocupa grande parte do suporte, aproximadamente 7 metros.

Os sinais conformam a temática principal desse painel. São figuras ovaladas e arredondadas, que se diferenciam como em uma declinação de formas, uma variação a partir de três unidades não figurativas simples, o ponto, o traço e o círculo (Figuras 21, 22A, B e D e 23D). Estão presentes também nesse painel algumas unidades figurativas (Figuras 22C, 23A, B e C).

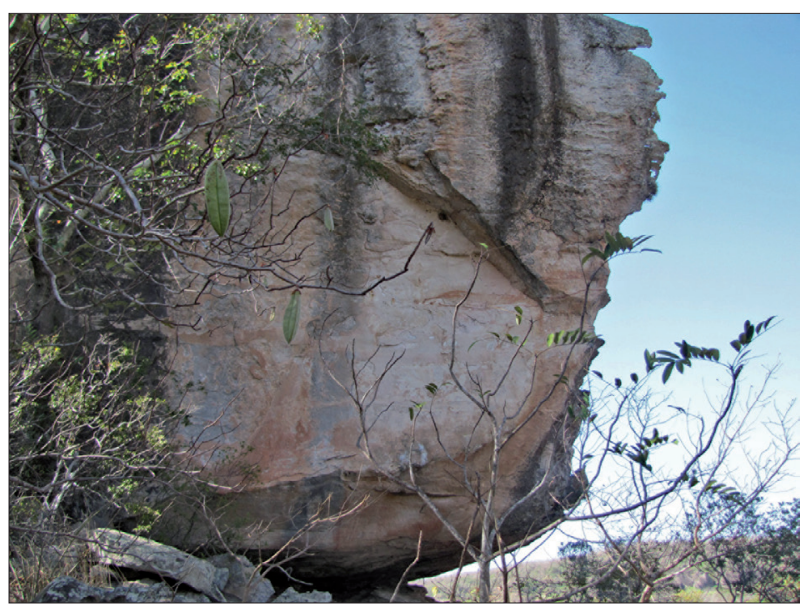

Figura 17. Painel 4 - Vista geral do painel. Foto: Carolina Guedes, 2011.

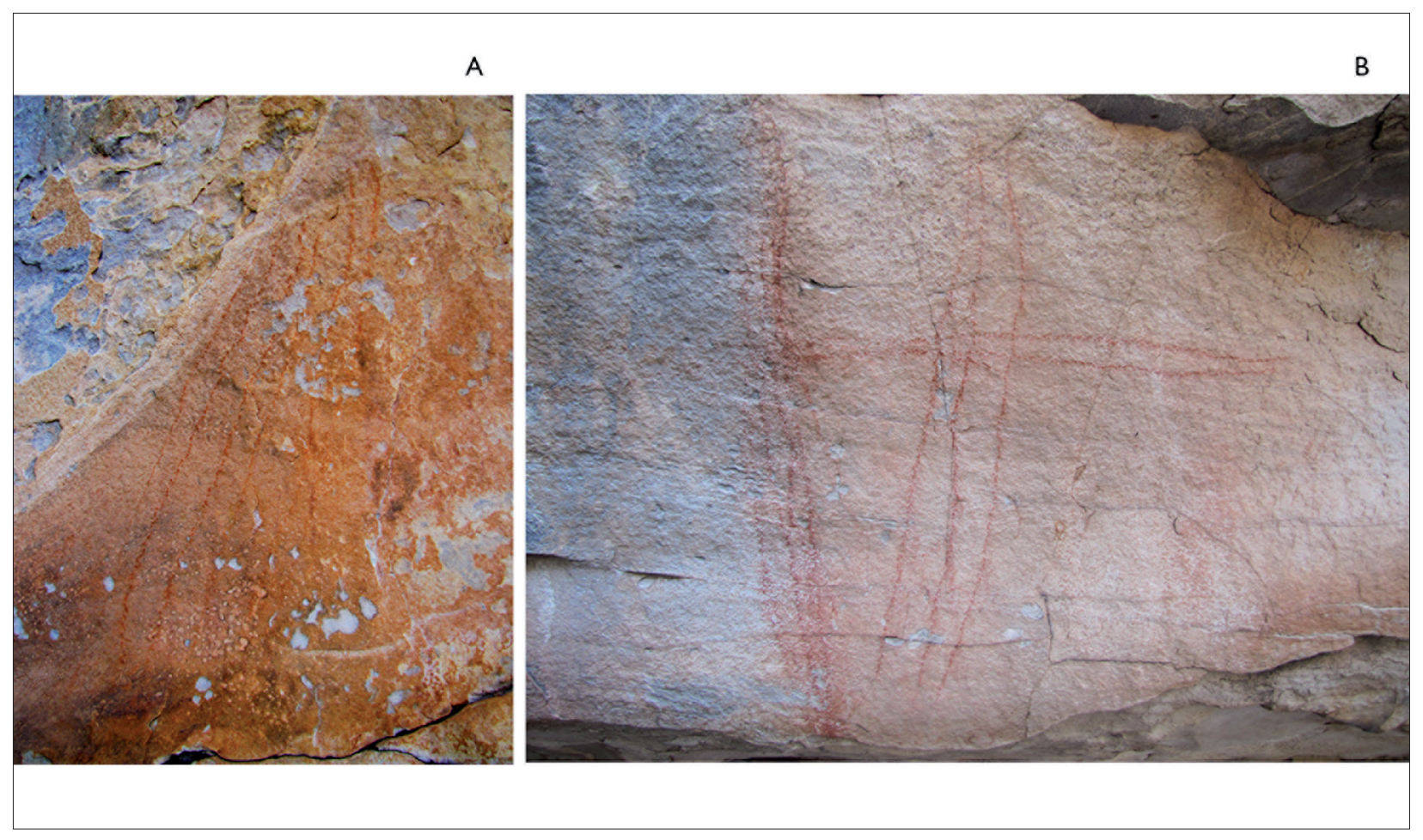

Figura 18. Detalhe do painel 4 - (A) e (B) Detalhes do desenho em crayon. 18A imagem manipulada digitalmente - Photoshop. Foto: Carolina Guedes, 2011.

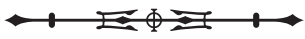




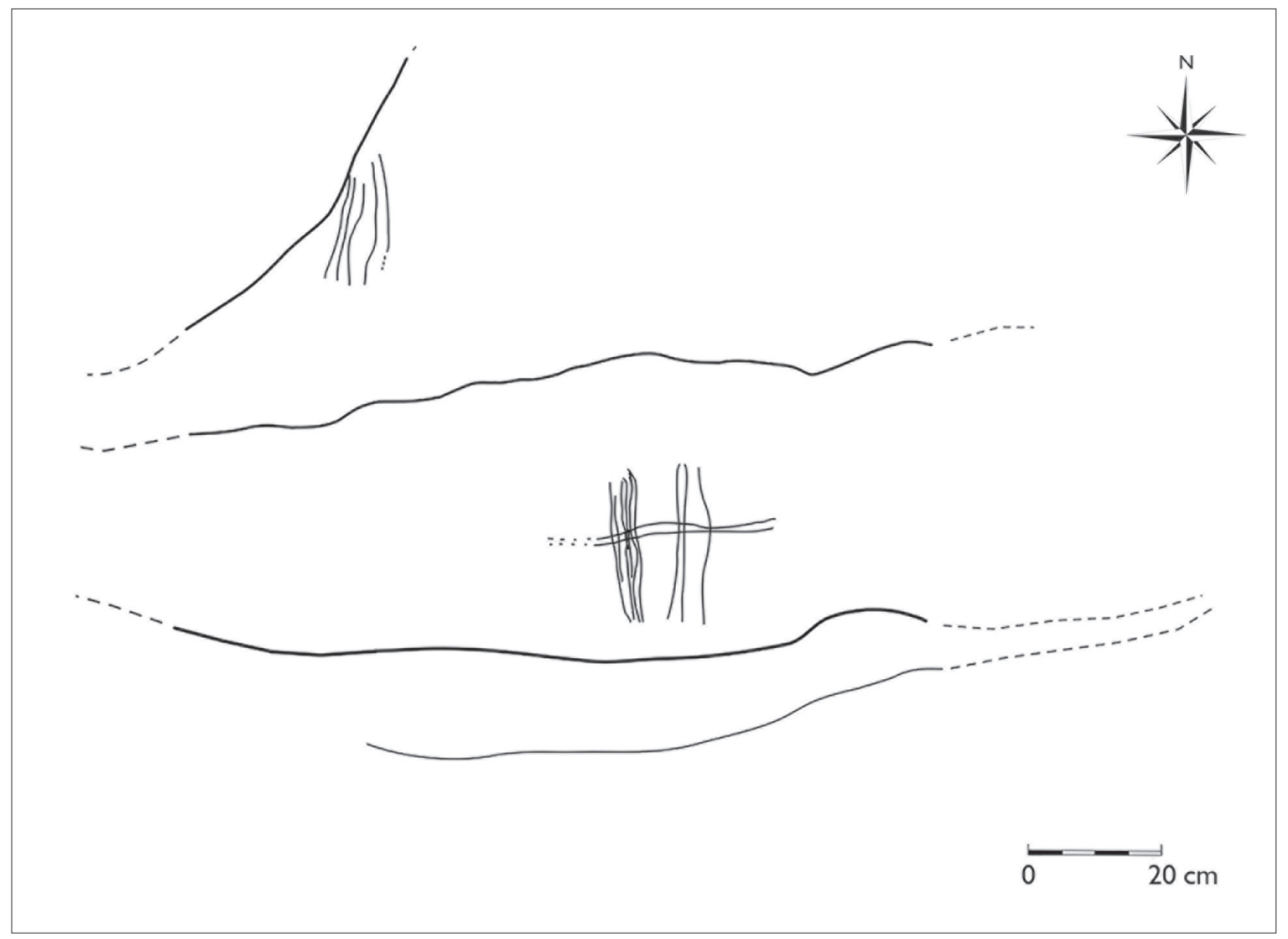

Figura 19. Plano diretor escalado com a localização dos crayons. Imagem vetorizada: Carolina Guedes, 2011.
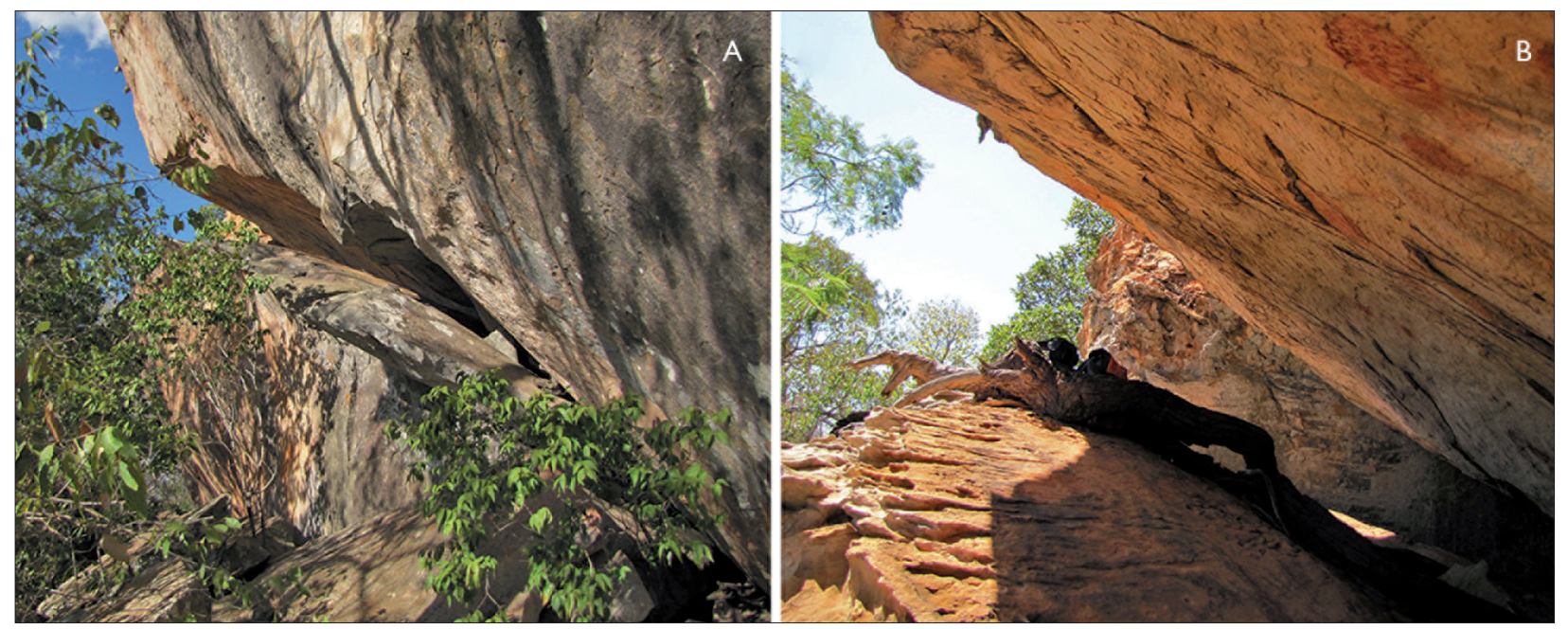

Figura 20. Painel 5: (A) Vista geral; (B) Detalhe da abertura. As pinturas estão localizadas sob o teto, vê-se acima, à direita, uma pintura em tom vermelho. Fotos: Carolina Guedes, 2011.

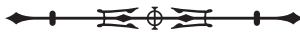




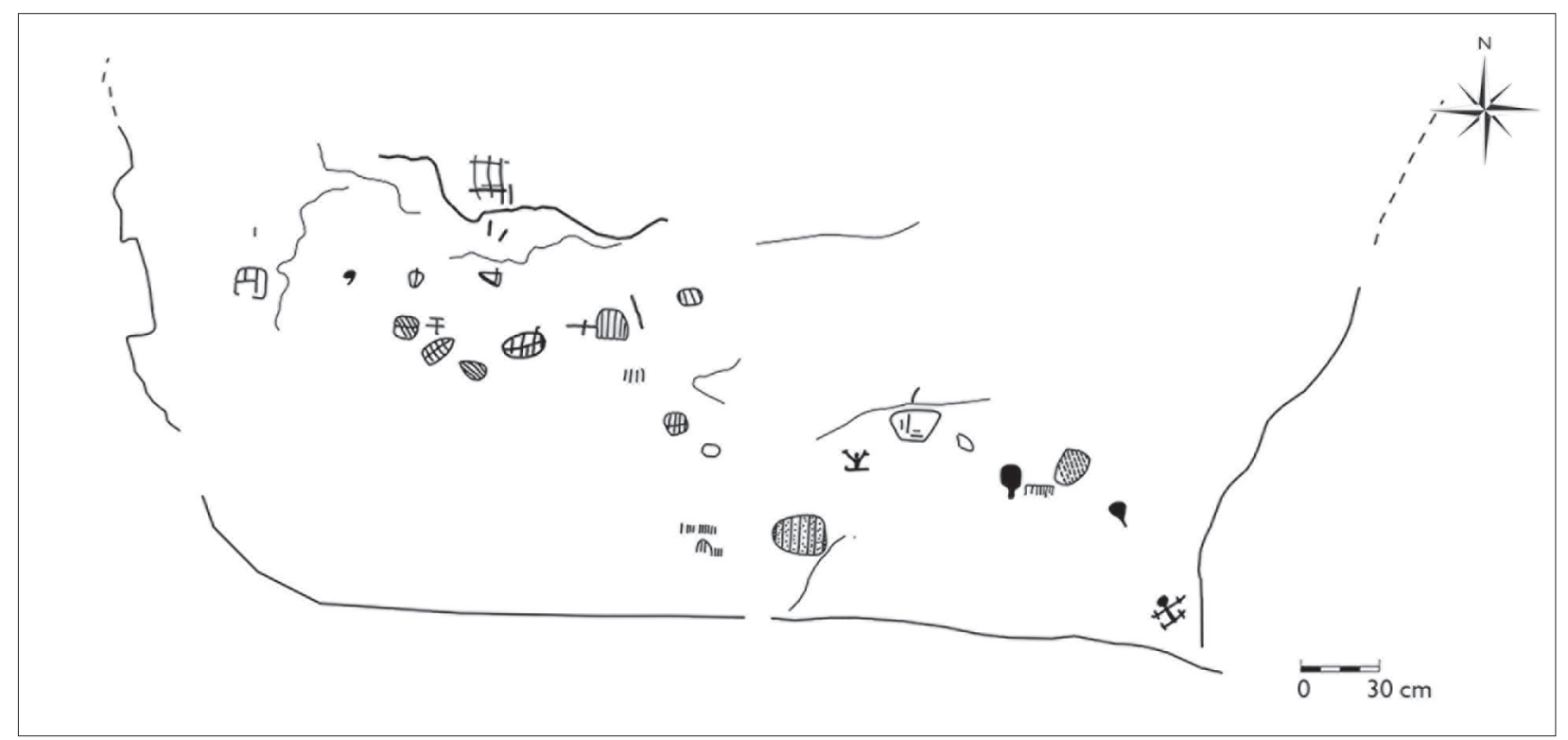

Figura 21. Painel 5 - Plano diretor escalado. Imagem vetorizada: Carolina Guedes, 2011.

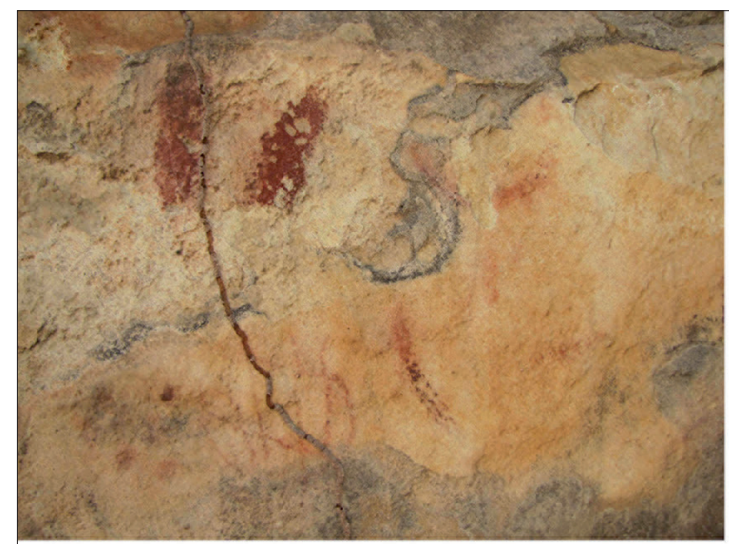

A
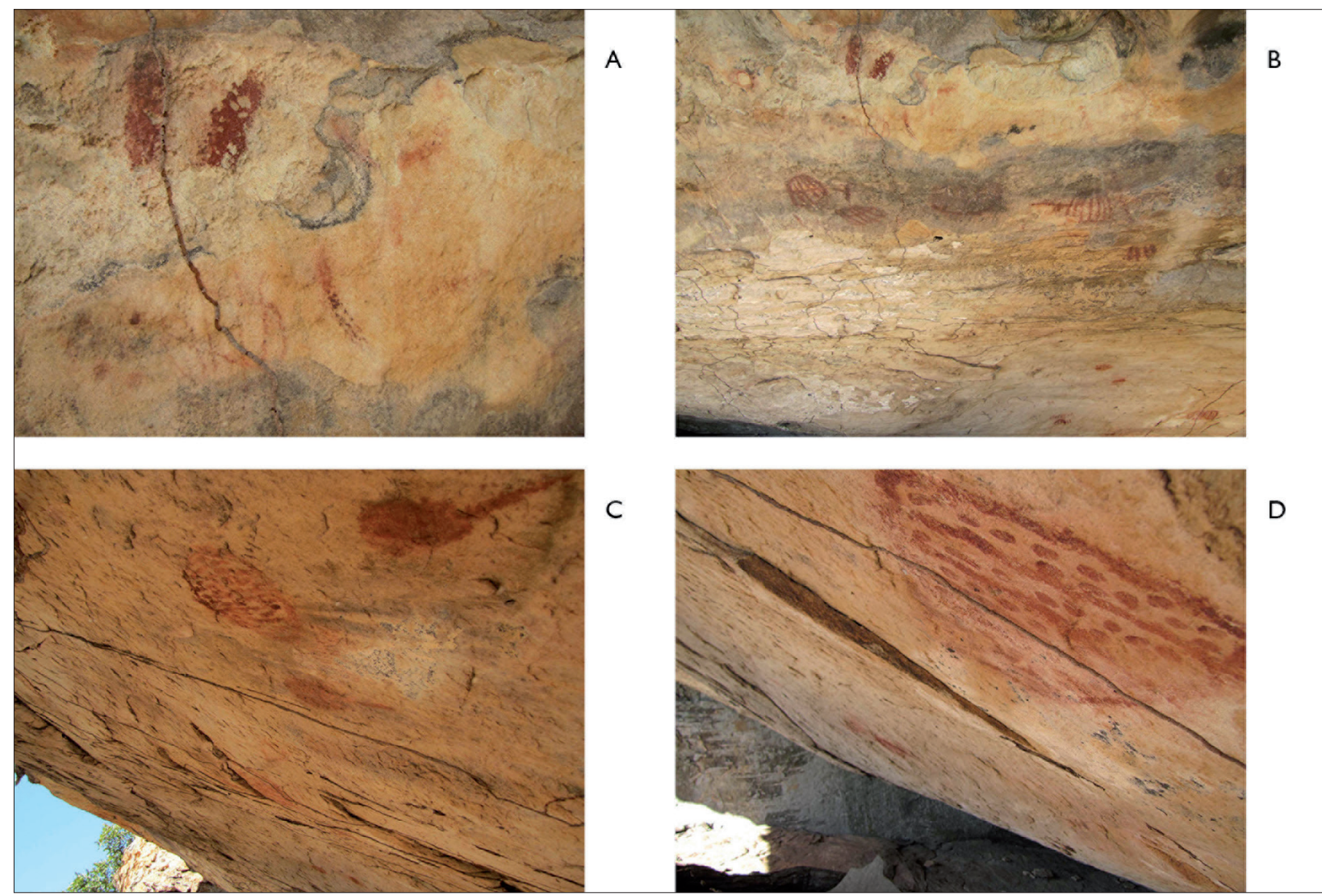

Figura 22. Detalhe do painel 5. (A), (B) e (D): Pinturas não-figurativas; (C): Pinturas figurativas. Fotos: Carolina Guedes, 2011.

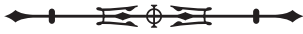



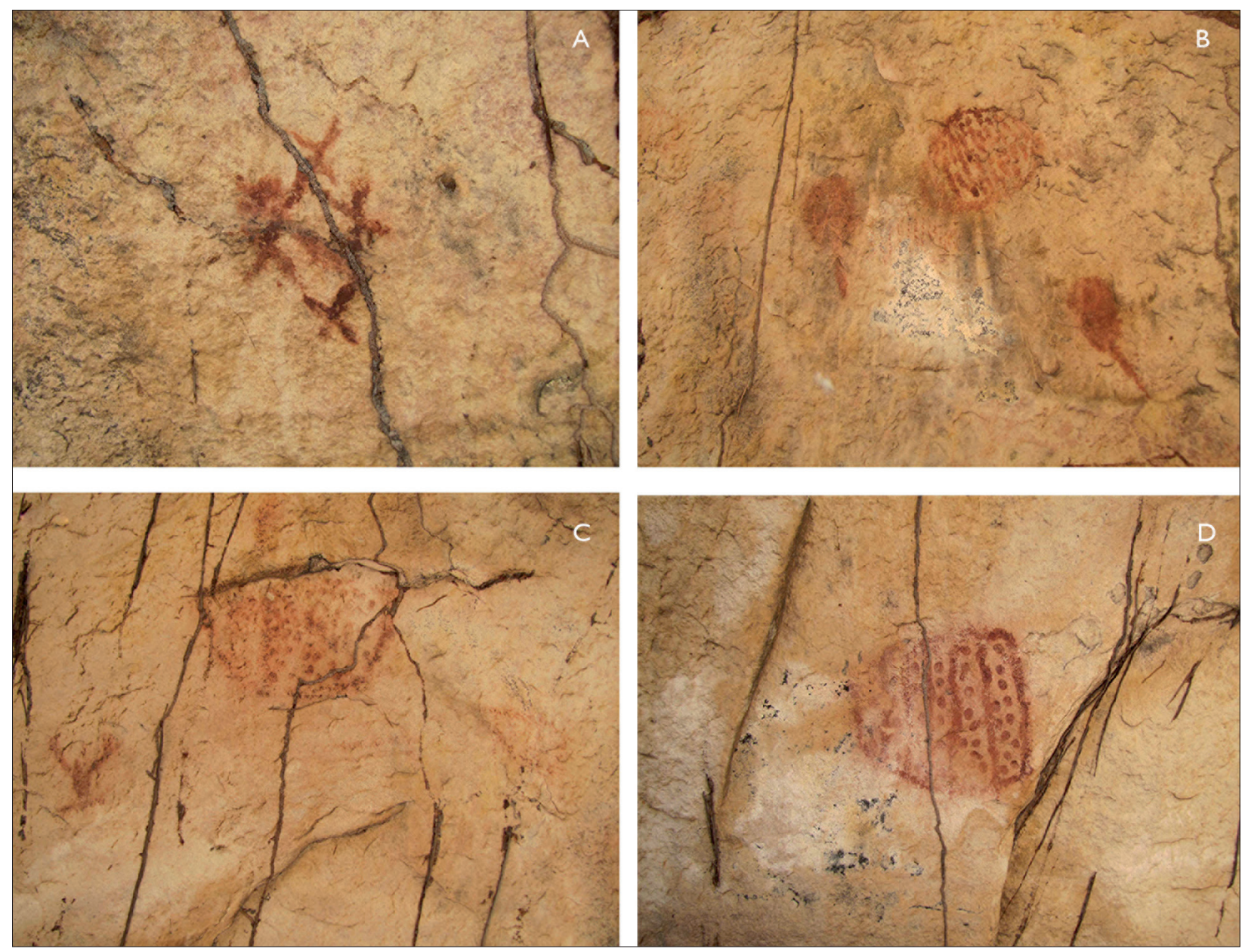

Figura 23. Detalhe do painel 5. (A), (B) e (C): Pinturas figurativas; D: Pinturas não-figurativas. Fotos: Carolina Guedes, 2011.

\section{PAINEL 6}

O sexto painel apresenta poucas unidades, sendo uma delas um antropomorfo extremamente vestigial (Figura 24). Porém, como nos demais painéis, os sinais são responsáveis pela temática central (Figuras 25 e 26).

\section{PAINEL 7}

O sétimo e último painel é também o mais distante da entrada principal do sítio. Os registros pintados encontramse sobre o teto de uma pequena abertura, bem próximo ao chão, aproximadamente a 1,05 m (Figura 27). Trata-se, na sua maioria, de construções elaboradas de sucessão de pontos (Figuras 28 e 29).

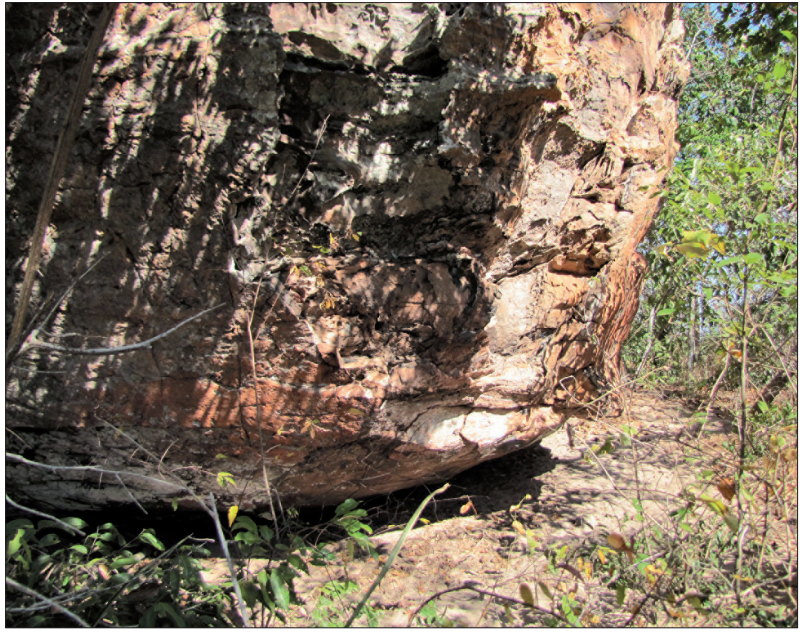

Figura 24. Painel 6 - Vista geral. Foto: Carolina Guedes, 2011.

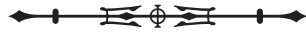



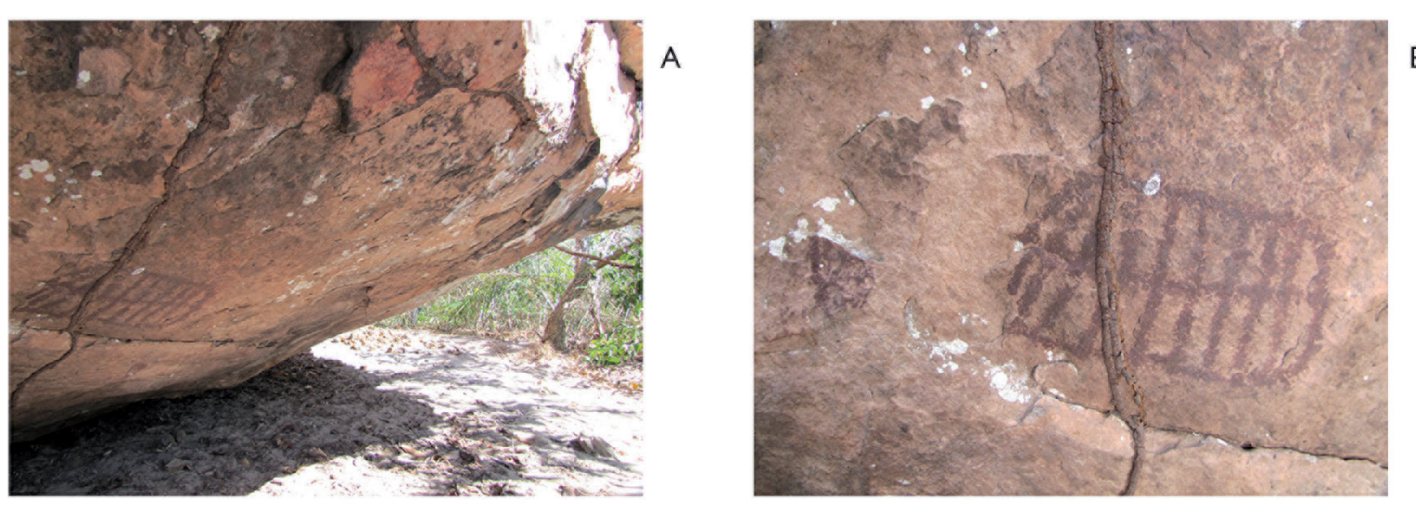

B

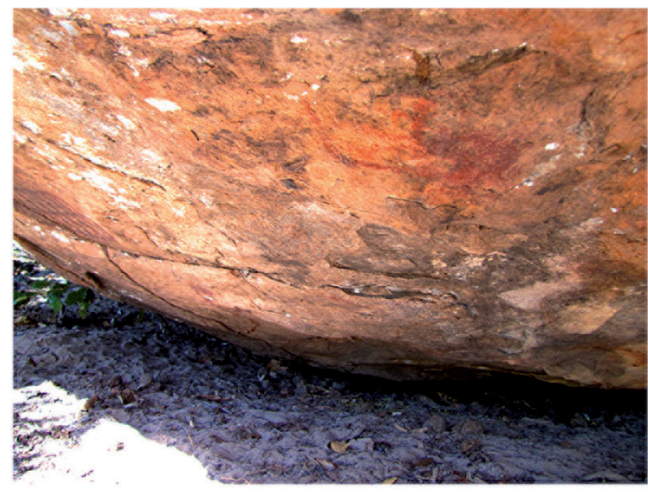

C

Figura 25. Detalhe do painel 6. (A) e (B) pintura não-figurativa quadrangular. (C) Detalhe pintura em tom alaranjado. Fotos: Carolina Guedes, 2011.

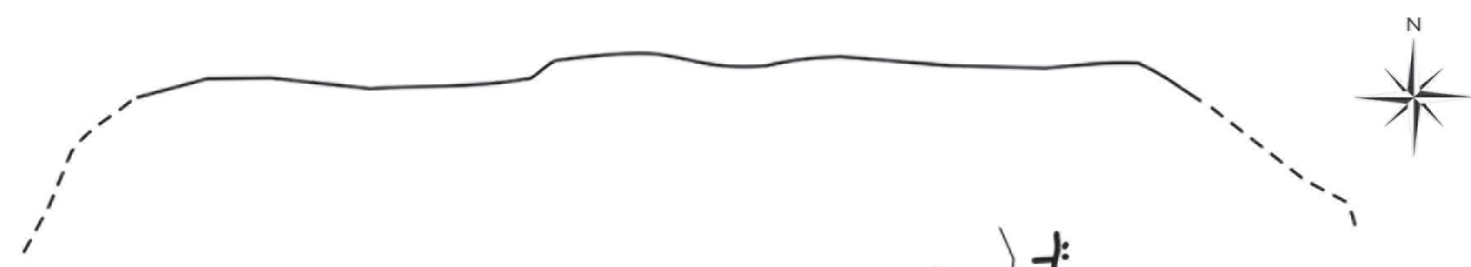

d)

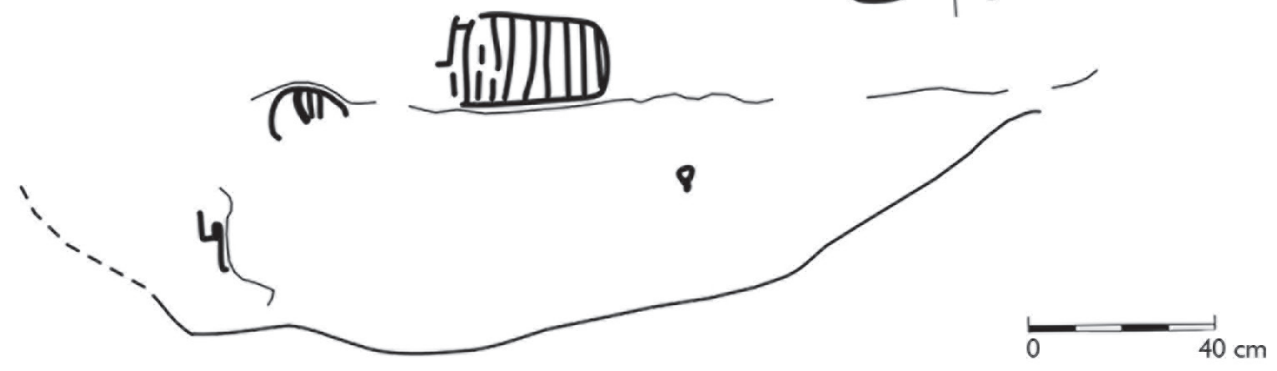

Figura 26. Painel 6 - Plano diretor escalado. Pintura figurativa vestigial (à esquerda) e não-figurativas. Imagem vetorizada: Carolina Guedes, 2011.

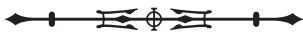




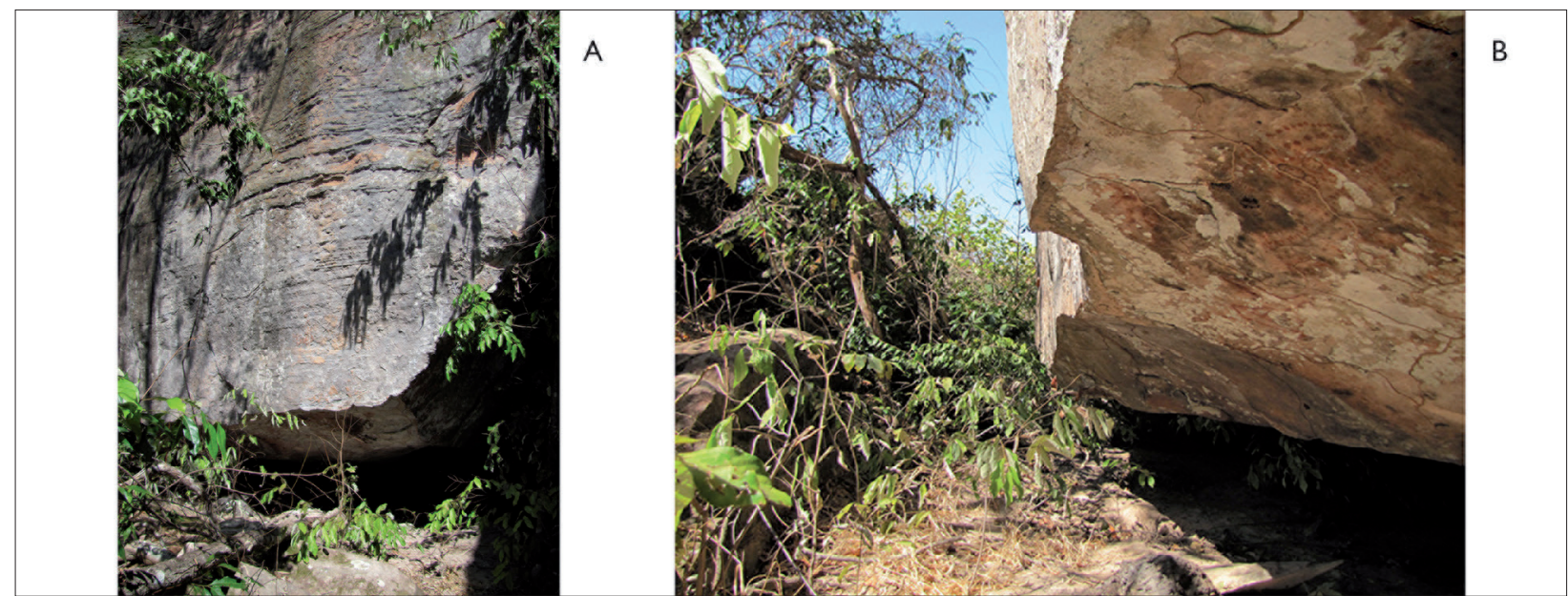

Figura 27. Painel 7. (A) Vista geral do painel; (B) Detalhe do teto onde se localizam as pinturas em tom vermelho. Nota-se à direita a unidade estruturada por pontos. Fotos: Carolina Guedes, 2011.
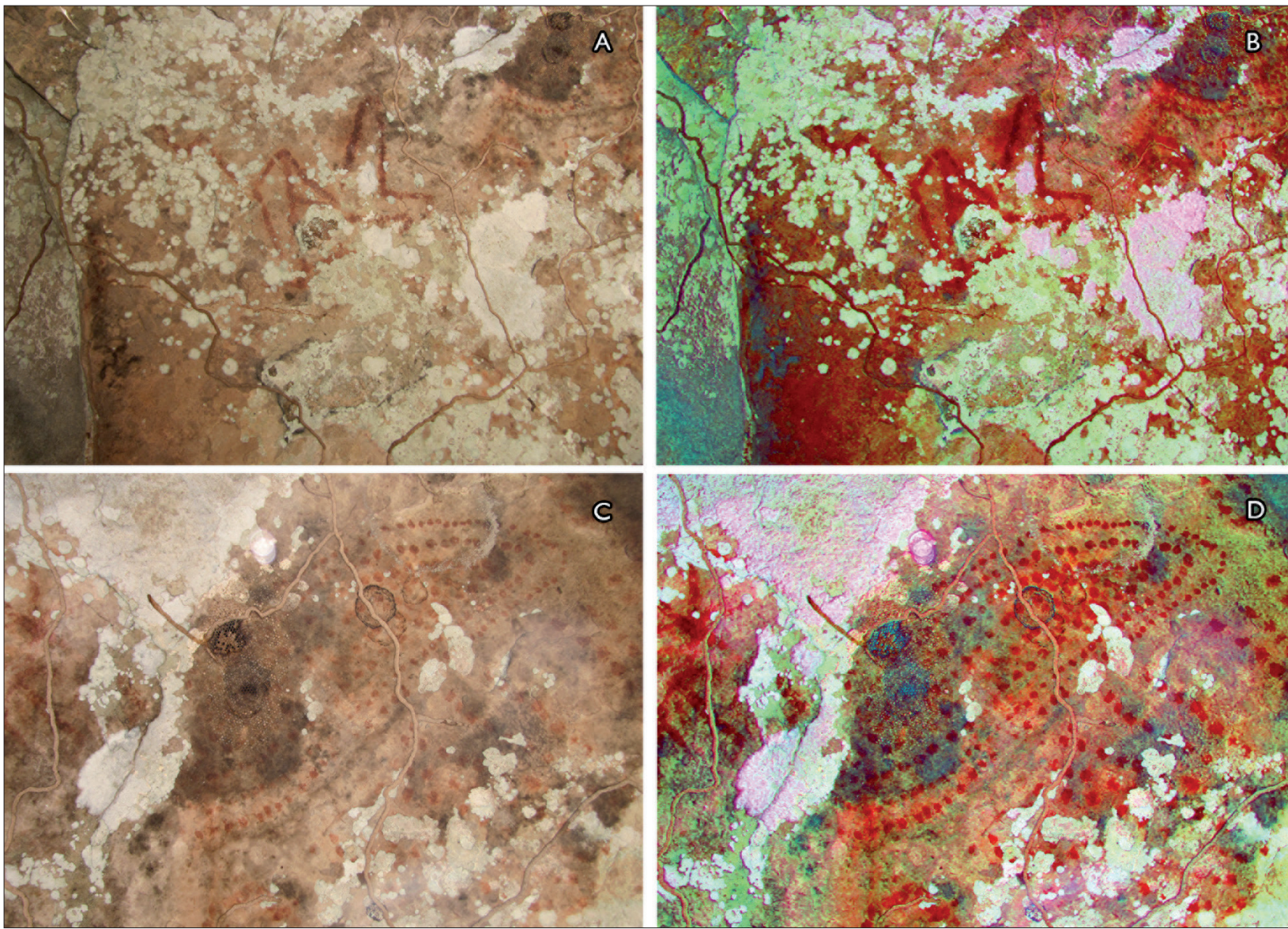

Figura 28. Painel 7. Pinturas não-figurativas. As figuras (A) e (C) mostram os grafismos como observado em campo. As figuras (B) e (D) mostram os grafismos após o tratamento através do software DStretch (YDR). Fotos: Carolina Guedes, 2011. 


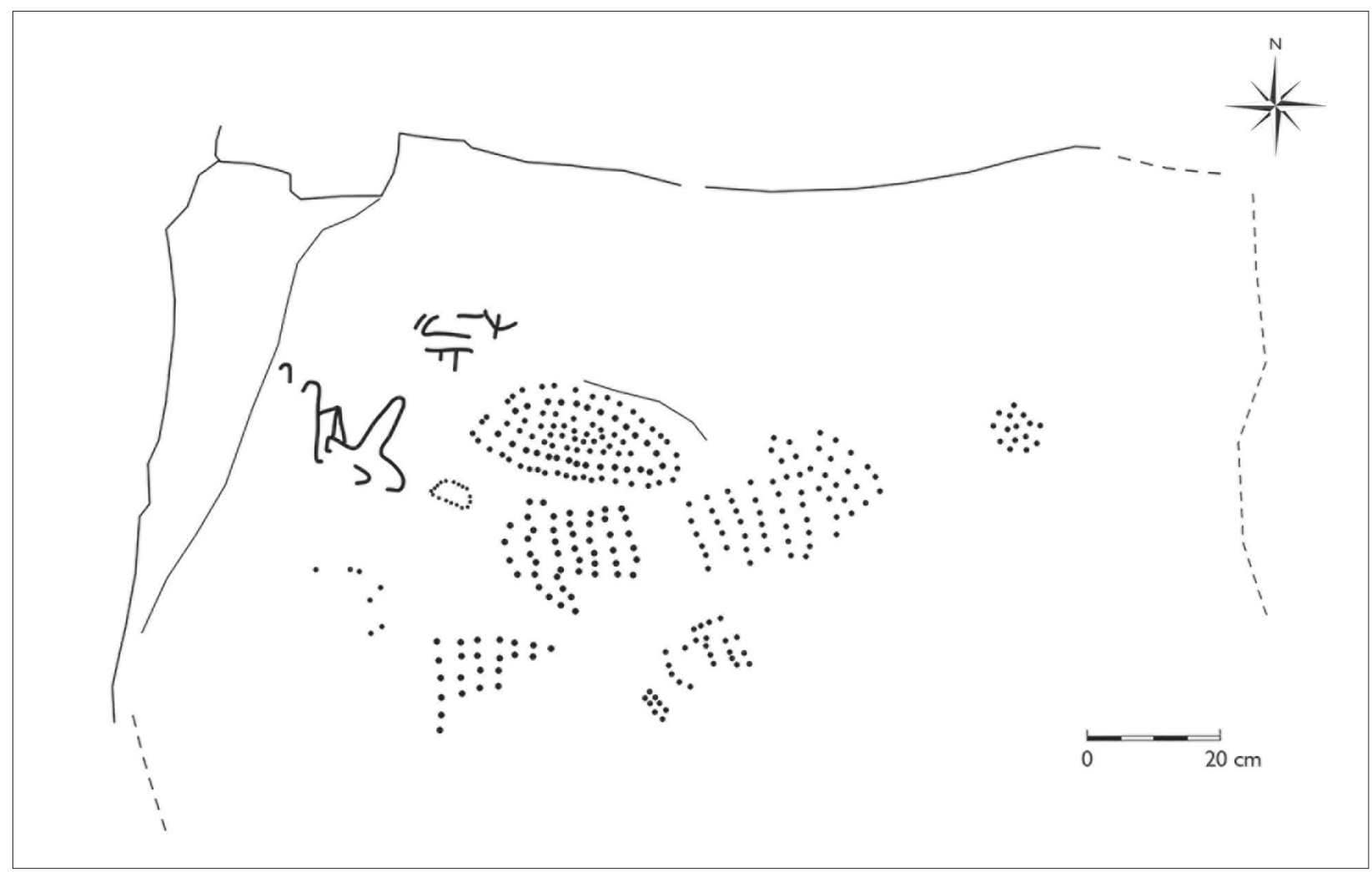

Figura 29. Plano diretor escalado com a localização das pinturas. Imagem vetorizada: Carolina Guedes, 2011.

\section{CONSIDERAÇÕES SOBRE OS SUPORTES E AS PINTURAS}

A análise do sítio gerou dados para a compreensão de algumas questões pertinentes aos estudos de arte rupestre, tais como: como ocorreu a distribuição dos registros? De quais maneiras o suporte foi utilizado? Qual a relação entre temática e local? De que forma podemos compreender a organização desses suportes? Existe uma organização entre escolha do suporte, local de representação e temática? Podemos perceber a formação de um código visual? Podemos compreender a articulação de um discurso parietal?

Considerando esses questionamentos, podemos perceber no Painel 3 que a mudança de tonalidade observada é indicativo de uma construção simbólica intencional. Junta-se a isso sua seleção no suporte rochoso, já que o complicado acesso associado a uma representação figurativa é um importante indicativo de sua construção simbólica. $\bigcirc$ animal está associado ao local e vice-versa, juntos eles fazem sentido. Já a alta visibilidade do Painel 4 contrasta com a simplicidade dos seus grafismos, sendo percebidos apenas de forma vestigial.

Por sua vez, o Painel 5 se apresenta como o local de acesso mais complicado e sua construção simbólica parece estar diretamente relacionada a esse fato, quer dizer, a complexidade de acesso se reflete na complexidade do painel e das unidades nele presentes. Nesse painel, percebemos a utilização das irregularidades do suporte, o que apóia a proposta da construção dialética da mensagem no espaço parietal. Vemos presente a intrínseca relação entre o suporte rochoso e os registros gráficos na organização dessa 'linguagem simbólica'.

Notamos, na construção simbólica do Painel 6, visível diferenciação entre uma unidade principal e 
as demais unidades. É o caso da figura quadrangular preenchida por traços paralelos, apresentado nas Figuras $25 \mathrm{~A}$ e B. Nesse caso, existe uma relação semântica entre a escolha da cor e a representação e o seu local (Vialou, 1999, p. 214). Nesse painel, ela figura claramente como sinal principal da composição. Ainda que seja uma declinação formal, ou seja, nesse mesmo sítio encontramos representações similares, sua cor e seu tamanho são indicativos de uma construção simbólica singular.

O Painel 7, o mais afastado da entrada atual, está completamente escondido, indicando uma importante escolha. Ele parece ter sido feito para não ser visto, fato esse que parece, mais uma vez, estar intrinsecamente relacionado com o tratamento simbólico do local. A combinação de unidades simples, nesse caso o ponto, formou registros elaborados, como mostram as Figuras 27B e 28C e D. É o resultado da articulação de uma forma simples que ocasionou unidades complexas.

É perceptível a existência, nesse sítio, de uma dialética, uma relação intrínseca, entre os dispositivos rupestres e os suportes rochosos, ou seja, entre a temática concebida e a totalidade do sítio. Analisando a influência do suporte natural na concepção dos painéis, não apenas os registros foram objeto de inferência sobre o processo cognitivo, mas também a relação existente entre as pinturas, os desenhos e a utilização do suporte. Portanto, compreender as estruturas de formação simbólica do Conjunto da Falha nos permitiu reconhecer áreas específicas de diálogo entre os diversos elementos que o constituem.

O que se notou foi a especificidade de cada nicho. A totalidade de unidades gráficas, em torno de 83 figuras, foi organizada em sete painéis, localizados em nichos especíicos, com temáticas originais. Cada local escolhido apresentou um conjunto particular, inteiramente diferente do outro.

De maneira geral, não há um relevo semelhante ao outro, assim como não há um painel semelhante ao outro. Isso indica uma originalidade importante e uma articulação única entre a topografia do local selecionado, o suporte rochoso e a temática tratada.

Nesse contexto, a utilização do espaço parietal não poderia ser mais heterogênea, na qual a relação entre 0 espaço e o dispositivo parietal parece seguir uma única regra: a diversidade.

Se os painéis, de maneira geral, são distintos uns dos outros, o mesmo não pode ser afirmado quando analisamos as unidades gráficas separadamente. Como exposto anteriormente, é perceptível a recorrência de tipos específicos de sinais entre a Falha e outros sítios da região. A partir dessas recorrências, podemos compreender a existência de um código visual regional. As mesmas marcas simbólicas estão sendo dispostas em variados locais, sinalizando a paisagem e organizando os dispositivos rupestres.

Quando analisamos os painéis rupestres sob o viés de uma temática geral (os sinais geométricos), as escolhas pelos locais de representação não seguiram nenhum padrão definido, uma vez que encontramos painéis em áreas de fácil e de difícil visualização e acesso. Porém, ao nos questionarmos sobre a relação suporte/registro gráfico, vemos evidenciada uma constante na construção simbólica do sítio.

Essa constante aparece na forma de uma organização dual entre os seguintes elementos: fácil acesso/simplicidade versus difícil acesso/complexidade, fato esse bem ilustrado pelos Painéis 4 e 6, para a primeira, proposição e pelos Painéis 5 e 7, para a segunda.

A relação entre fácil e difícil acesso foi estabelecida considerando o esforço necessário realizado tanto pelo pintor quanto pelo observador para construir/visualizar os painéis rupestres.

A dificuldade de acesso envolve, sobretudo, a necessidade de escalar o afloramento e/ou se arrastar em pequenas entradas para conseguir chegar ao local sem essas ações, não é possível visualizar por completo ou mesmo construir esses painéis específicos. Por outro lado, os painéis de acesso fácil são prontamente visualizados pelos caminhos existentes no sítio. 
Podemos, talvez, excetuar dessa interpretação o Painel 1. Dentro dessa proposta analítica, esse painel parece se destacar pela originalidade temática, apresentando a maior quantidade de elementos figurativos. Considerando que esse complexo painel se localiza em plena vista, a relação temática/local foi construída de maneira original. Ao não respeitar a dualidade acima proposta, esse painel se coloca como uma terceira forma de organização de um discurso social, marcando o espaço pela sua diferença.

Portanto, é perceptível que os locais foram estrategicamente escolhidos e a intenção da escolha está diretamente relacionada com o diálogo, com a articulação de uma mensagem criada a partir da interrelação do suporte e das temáticas.

Compreendemos, assim, que existe, na construção do código visual desse sítio, uma dialética entre continuidade comunitária (sinais complexos repetidos), estrutura (sinais simples) e inovação (sinais originais presentes apenas nesse sítio). Dessa forma, quando analisados em contexto, esses dados permitem evidenciar comportamentos sociais, através das expressões cognitivas dos grupos responsáveis por sua criação.

\section{CONSIDERAÇÕES FINAIS}

Este artigo explorou, por meio do viés da Arqueologia Cognitiva, uma análise estrutural sobre o comportamento simbólico de homens e mulheres do pretérito, que transitaram e marcaram a região da Cidade da Pedra, no Mato Grosso.

As análises dos conjuntos de painéis evidenciaram a importância do suporte na construção das mensagens. Isso significa que podemos perceber a articulação do discurso parietal com o suporte, que se apresentou como regulador e como influenciador da elaboração dos discursos.

Esse tipo de estudo permitiu uma compreensão sobre a forma de organização de discursos específicos, marcados por cada painel, que, em sua totalidade, foram organizados sob uma mesma abordagem.
Essas observações, além de serem fundamentais para compreendermos a partir de que formas homens e mulheres pretéritos simbolizavam sua experiência, conhecimento, crenças, também nos deixou inferir sobre o processo de construção desse tipo de representação simbólica, um universo temático com grande quantidade de figuras geométricas e, em menor número, de unidades figurativas, como o lagarto e algumas unidades humanas vestigiais, singularizadas pela localização dentro do sítio. É através da articulação desses elementos com o suporte rochoso que entendemos a "codificação simbólica" (Paillet, 2006, p. 95) do sítio da Falha, evidenciada pela proposta da dualidade na organização do discurso.

A nossa pesquisa tratou de alguns aspectos do comportamento, guiados por dois elementos do universo cognitivo humano: a percepção (do local) e a seleção (temática). Partindo dessas duas bases do comportamento, formulamos questões sobre a organização do código visual presente no sítio da Falha.

As variações sobre as organizações estruturais nos painéis rupestres são evidentes, trata-se de construções conscientes de mensagens específicas, elaboradas em comunidade. A seleção das formas declinadas do Painel 5 é um exemplo de como podemos perceber uma semântica na seleção e na organização dos discursos. Esses registros são importantes exatamente pela sua semelhança.

No entanto, um desdobramento de formas se apresentou, articulando os registros gráficos em uma proposta temática emoldurada pela topografia dos suportes rochosos. $\bigcirc$ discurso parietal foi gravado nessa interseção dialética.

Os caminhos relativamente estreitos, que ligam os diversos afloramentos, funcionaram como guias de nosso percurso pelo conjunto total do sítio. Compreendemos que esse entorno foi fator importante na construção simbólica do local, com variações entre a visibilidade e sua face escondida, ainda que as vias utilizadas pelos homens e mulheres pretéritos fossem distintas das utilizadas atualmente. 


\section{AGRADECIMENTOS}

Agradecemos à Fundação de Amparo à Pesquisa do Estado de São Paulo (FAPESP) pelo financiamento integral da pesquisa de doutoramento, da qual originou o presente artigo.

\section{REFERÊNCIAS}

ANATI, E. La genèse de l'art. In: ANATI, E. (Ed.). Aux origines de l'art. Traduit de l'italien par Jérôme Nicolas. Paris: Libraire Arthème Fayard, 2003.

KEROUAliN, F. M. Conjunto da Falha. In: VIALOU, A. (Ed.). Préhistória do Mato Grosso: Cidade de Pedra. São Paulo: EDUSP, 2006. p. 71-83. v. 2.

KEROUALIN, F. M. Contribution à l'étude d'un site d'art rupestre Morro da Falha (Mato Grosso) Brésil: Maitrise de Préhistoire. Paris: Sorbonne, 1988. 144 p.

LEROI-GOURHAN, A. Réflexions de méthode sur l'art paléolithique. Bulletin de la Société Préhistorique Française, Paris, tome 63, n. 1, p. 35-49, 1966.

LEROI-GOURHAN, A. La fonction des signes dans les sanctuaires préhistoriques. Bulletin de la Société Préhistorique Française, Paris, tome 55, n. 5-6, p. 307-321, 1958.

LEWIS-WILLIAMS, D.; PEARCE, D. The consciousness contract. In: LEWIS-WILLIAMS, D.; PEARCE, D. (Ed.). Inside the Neolithic mind. London: Thames \& Hudson, 2005. p. 37-59.

PAILLET, P. Os abrigos vermelhos. In: VIALOU, A. (Ed.). Préhistória do Mato Grosso: Cidade de Pedra. São Paulo: EDUSP, 2006. p. 91-123. v. 2.
PINKER, S. The language instinct. New York: Harper Perennial/ Modern Classics, 2007.

RAPHÄEL, M. Prehistoric cave paintings. Translation by Norbert Guterman. New York: Pantheon Books, 1945.

RENFREW, C. Towards a Cognitive Archaeology. In: RENFREW, C.; ZUBROW, E. B. W. (Ed.). The ancient mind: elements of Cognitive Archaeology. Cambridge: Cambridge University Press, 1995. p. 3-12.

SAUVET, G. Les signes pariétaux. In: Groupe de Refléxion sur l'Art Pariétal Paléolithique (Ed.). L'art pariétal paléolithique: techniques et méthodes d'études. Paris: CTHS, 1993. p. 219-234.

SCHAAFSMA, P. Form, content and function: theory and method in North American rock art studies. Advances in Archaeological Method and Theory, New York. v. 8, p. 237-277, 1985.

SEGAL, E. M. Archaeology and cognitive science. In: RENFREW, C.; ZUBROW, E. B. W. (Ed.). The ancient mind: elements of cognitive archaeology. Cambridge: Cambridge University Press, 1994. p. 22-28.

SILVA, V. C. F. A exploração dos recursos litológicos na região da Cidade de Pedra, Rondonópolis, MT. 2005. 114 f. Dissertação (Mestrado em Arqueologia) - Museu de Arqueologia e Etnologia, Universidade de São Paulo, São Paulo, 2005.

VIALOU, D. Arte rupestre e a paisagem da Cidade de Pedra. In: VIALOU, A. (Ed.). Pré-história do Mato Grosso: Cidade de Pedra. São Paulo: EDUSP, 2006. p. 51-59. v. 2.

VIALOU, D. L'art Paléolithique. In: OTTE, M.; VIALOU, D.; PLUMET, P. (Ed.). La Préhistoire. Paris: Boeck, 1999. p. 213-289.

WILSON, E. O. Consilience: the unity of knowledge. New York: First Vintage Books, 1999.

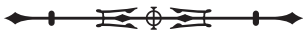


